\title{
Combined deletion of p38y and p38ס reduces skin inflammation and protects from carcinogenesis
}

\author{
Rafal Zur ${ }^{1}$, Laura Garcia-Ibanez ${ }^{1}$, Angel Nunez-Buiza ${ }^{1}$, Noelia Aparicio ${ }^{1}$, Georgios \\ Liappas $^{2}$, Alejandra Escós ${ }^{1}$, Ana Riscoㄹ, Angustias Page ${ }^{3}$, Cristina Saiz-Ladera ${ }^{3}$, \\ Dayanira Alsina-Beauchamp ${ }^{1}$, José Montans ${ }^{4}$, Jesús M. Paramio ${ }^{3}$ and Ana Cuenda ${ }^{1}$ \\ ${ }^{1}$ Department of Immunology and Oncology, Centro Nacional de Biotecnología/CSIC, Madrid, Spain \\ ${ }^{2}$ Molecular Biology Centre Severo Ochoa/CSIC-UAM, Madrid, Spain \\ ${ }^{3}$ Molecular Oncology Unit, CIEMAT and I+12 Biomedical Research Institute, University Hospital 12 de Octubre, Madrid, Spain \\ ${ }^{4}$ Centro Anatomopatológico, Camino de Vinateros, Madrid, Spain \\ Correspondence to: Ana Cuenda, email: acuenda@cnb.csic.es \\ Keywords: p38y, p38ס, skin, inflammation-associated cancer, knockout mice \\ Received: April 13,2015 Accepted: May 25, $2015 \quad$ Published: May 28, 2015
}

This is an open-access article distributed under the terms of the Creative Commons Attribution License, which permits unrestricted use, distribution, and reproduction in any medium, provided the original author and source are credited.

\section{ABSTRACT}

The contribution of chronic skin inflammation to the development of squamous cell carcinoma (SCC) is poorly understood. While the mitogen-activated protein kinase p38a regulates inflammatory responses and tumour development, little is known about the role of $\mathrm{p} 38 \mathrm{y}$ and $\mathrm{p} 38 \delta$ in these processes. Here we show that combined $\mathrm{p} 38 \mathrm{y}$ and $\mathrm{p} 38 \delta(\mathrm{p} 38 \mathrm{y} / \delta)$ deletion blocked skin tumour development in a chemically induced carcinogenesis model. $\mathrm{p} 38 \mathrm{y} / \delta$ deletion reduced TPA-induced epidermal hyperproliferation and inflammation; it inhibited expression of proinflammatory cytokines and chemokines in keratinocytes in vitro and in whole skin in vivo, resulting in decreased neutrophil recruitment to skin. Our data indicate that $\mathrm{p} 38 \mathrm{y} / \delta$ in keratinocytes promote carcinogenesis by enabling formation of a proinflammatory microenvironment that fosters epidermal hyperproliferation and tumourigenesis. These findings provide genetic evidence that $p 38 y$ and p38 have essential roles in skin tumour development, and suggest that targeting inflammation through $\mathrm{p} 38 \mathrm{y} / \delta$ offers a therapeutic strategy for SCC treatment and prevention.

\section{INTRODUCTION}

Skin squamous cell carcinomas (SCC) are the second most frequent human non-melanoma skin cancers, with an incidence of 16 in 100,000 people in Europe $[1,2]$. SCC arise from keratinocytes of the epidermis and oral mucosa, and are most commonly found in sunexposed areas. Other risk factors associated with SCC include tobacco and human papilloma virus infection [2]. Inflammatory processes often facilitate cancer development by promoting immune cell infiltration. These cells supply mitogenic growth mediators such as cytokines, which stimulate proliferation of epidermal cells carrying damaged DNA and of other stromal cell types in their vicinity, thus promoting oncogenesis [3]. In humans, chronic skin ulcers and lupus vulgaris are inflammatory skin diseases, which predispose patients to develop SCC $[4,5]$.
A number of signalling pathways are described to be important in SCC development [6-8]. Among them the mitogen-activated protein kinase (MAPK), and particularly the p38MAPK pathways are also central to inflammatory processes [9]. The p38MAPK group has four members encoded by different genes, p38 $\alpha$ (MAPK14),

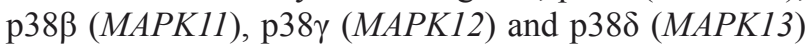
[10]. While the roles of the $\mathrm{p} 38 \alpha$ isoform have been widely studied in the context of inflammation and tumourigenesis [11-13], our knowledge of the in vivo role of $\mathrm{p} 38 \gamma$ and p38 $\delta$ in these processes [14] is still very limited. Recent

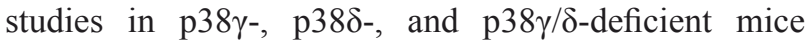
showed that these kinases are essential for the innate immune response and inflammation [9, 14-16]. Combined deletion of $\mathrm{p} 38 \gamma / \delta$ impairs production of proinflammatory cytokines in macrophages and dendritic cells in response to the bacterial lipopolysaccharide (LPS) [14]. p38 $\gamma / \delta$ deficient mice are less sensitive than wild type (WT) mice 
to LPS-induced septic shock and liver damage [14, 17]. Moreover, p38 $\gamma / \delta$ deficiency greatly reduced symptom severity and joint damage in a collagen-induced arthritis model [15] and led to attenuated colon inflammation in a dextran sodium sulphate (DSS)-induced colitis model [16]. In all experimental models of inflammation, $\mathrm{p} 38 \gamma / \delta^{-/}$ mice expressed lower IL-1 $\beta$ and TNF $\alpha$ levels [14-16] as well as displayed decreased immune cell recruitment [16].

In addition to a role for $\mathrm{p} 38 \gamma$ and $\mathrm{p} 38 \delta$ in inflammation, evidence from different cell-based assays shows that $\mathrm{p} 38 \gamma$ and $\mathrm{p} 38 \delta$ play both tumour-promoting and tumour-suppressing roles [12, 14, 18-23]. Studies in mice deficient in $\mathrm{p} 38 \gamma, \mathrm{p} 38 \delta$, or both nonetheless show that these kinases have a pro-tumourigenic role and are needed for tumour development; $\mathrm{p} 38 \delta$ deficiency reduced tumour formation in the chemical DMBA/TPA (7,12-dimethylbenz[a]anthracene/12-Otetradecanoylphorbol-13-acetate)-dependent model of skin carcinogenesis and in K-Ras-driven lung carcinogenesis [24]. Combined p38 $\gamma$ and p38 $(\mathrm{p} 38 \gamma / \delta)$ deletion severely reduces chemical azoxymethane (AOM)/DSS-induced colon tumour formation in a colitis-associated model of colorectal cancer (CAC) [16]. Moreover, it has been shown that $\mathrm{p} 38 \gamma / \delta$ are central to $\mathrm{CAC}$ through regulation of haematopoietic cell response to injury, by linking tumourigenesis with inflammation [16].

The roles of $\mathrm{p} 38 \gamma$ and $\mathrm{p} 38 \delta$ in skin carcinogenesis and inflammation have not been fully characterized and remain largely unknown. The in vivo contribution of $\mathrm{p} 38 \gamma$ to skin tumour development has not been studied. p38 $\gamma$ and $\mathrm{p} 38 \delta$ have compensatory and redundant functions [25]; [14-16], therefore it is important to examine the role of these kinases together. The two-stage DMBA/ TPA chemical carcinogenesis model depends on proinflammatory processes [26], and we used this method to analyse $\mathrm{p} 38 \gamma$ and $\mathrm{p} 38 \delta$ activity in skin inflammation and skin tumour promotion/progression. We found that lack of $\mathrm{p} 38 \gamma$ and $\mathrm{p} 38 \delta$ reduced the inflammatory response in skin by regulating cytokine and chemokine production as well as leukocyte recruitment. In addition, p38 $\gamma$ or $\mathrm{p} 38 \delta$ deletion reduced skin tumour formation compared to WT, and interestingly, p38 $\gamma / \delta$-deficient mice were much more resistant to DMBA/TPA-induced tumourigenesis. This study provides a genetic demonstration that signalling downstream of $\mathrm{p} 38 \gamma$ and of $\mathrm{p} 38 \delta$ is essential for tumour formation in the skin, and offers further insights into the biological functions of $\mathrm{p} 38 \gamma$ and $\mathrm{p} 38 \delta$, the two leaststudied p38MAPK. Our work shows the pro-oncogenic role of $\mathrm{p} 38 \gamma$ and $\mathrm{p} 38 \delta$ in the skin, and confirms these two kinases as potential targets for cancer treatment and/or prevention.

\section{RESULTS}

\section{p38 $\gamma$ and p38 $\delta$ are essential for skin tumourigenesis}

To date there have been few studies showing p38y and/or p38 expression levels in different types of cancer including human SCC. Consultation of the Oncomine/ Compendia Bioscience database [27] showed no clear, consistent $\mathrm{p} 38 \gamma$ and $\mathrm{p} 38 \delta$ expression pattern in the few SCC cases available (Figure S1). We therefore analysed $\mathrm{p} 38 \gamma$ and $\mathrm{p} 38 \delta$ function in DMBA/TPA-induced skin carcinogenesis, using C57BL/6 WT, p38 $\gamma-$, p388- and $\mathrm{p} 38 \gamma / \delta$-deficient mice. We found that tumour incidence (percentage of tumour-bearing mice) and tumour number per mouse were lower in $\mathrm{p} 38 \gamma$ - and $\mathrm{p} 38 \gamma / \delta$-deficient mice than in WT mice; in addition, tumours (papillomas) developed on $\mathrm{p} 38 \gamma / \delta^{-/-}$mouse skin at week 19 disappeared after week 20 (Figure 1A). We also confirmed that p38 deficient mice showed a decrease in tumour development compared to WT mice ([24], Figure 1A). p38 expression in WT skin was higher in the papilloma compartment than in the surrounding skin (non-tumour tissue), with the opposite expression pattern for p38 $\gamma$ (Figure 1B, 1C). We did not find compensatory changes in mRNA or protein expression of the $\mathrm{p} 38 \mathrm{MAPK}$ isoforms after loss of $\mathrm{p} 38 \gamma$ or p38 (Figure 1B, 1C). p38 $\alpha$, another p38MAPK isoform, was expressed equally in papilloma and in surrounding skin (Figure 1B, 1C). Analysis with phospho-p38specific antibody showed that $\mathrm{p} 38 \delta$, but not $\mathrm{p} 38 \gamma$ was phosphorylated in papillomas (Figure 1B), suggesting a role for this kinase in skin tumour development.

There was no obvious difference in the histological appearance of papillomas between WT, p38 $\gamma^{-/-}$and $\mathrm{p} 38 \delta^{-/-}$ genotypes (Figure 1D). In WT and p38 $\gamma^{-/-}$mice, papilloma size was similar during DMBA/TPA treatment, whereas $\mathrm{p} 38 \delta$ deletion led to a brief delay in tumour growth. Towards the end of the experiment, the distribution in tumour size was similar in WT, p38 $\gamma^{-/-}$and $\mathrm{p} 38 \delta^{-/}$mice (Figure 1E). Immunofluorescence analysis of tumour sections from $\mathrm{p} 38 \gamma^{-/}$and $\mathrm{p} 38 \delta^{-/}$mice compared to WT mice showed no differences in the percentage of BrdU-positive cells (Figure 1F) and in cells positive for phosphorylated STAT3 (signal transducer and activator of transcription 3) (Figure 1G), which is essential for keratinocyte proliferation and neoplastic transformation. These results and the reduced tumour incidence in $\mathrm{p} 38 \gamma^{-}$ 1- and $\mathrm{p} 38 \delta^{-1-}$ compared to WT mice, with no apparent change in tumour size or growth, suggest a $\mathrm{p} 38 \gamma / \mathrm{p} 38 \delta$ function in early stages of skin tumour formation.

Compared to WT and $\mathrm{p} 38 \gamma / \delta^{-/-}$mice, $\mathrm{p} 38 \gamma^{-/}$and $\mathrm{p} 388^{-/}$mice had an intermediate phenotype in skin tumour formation (Figure 1A), which might indicate isoform redundancy, as reported in other biological processes [14- 

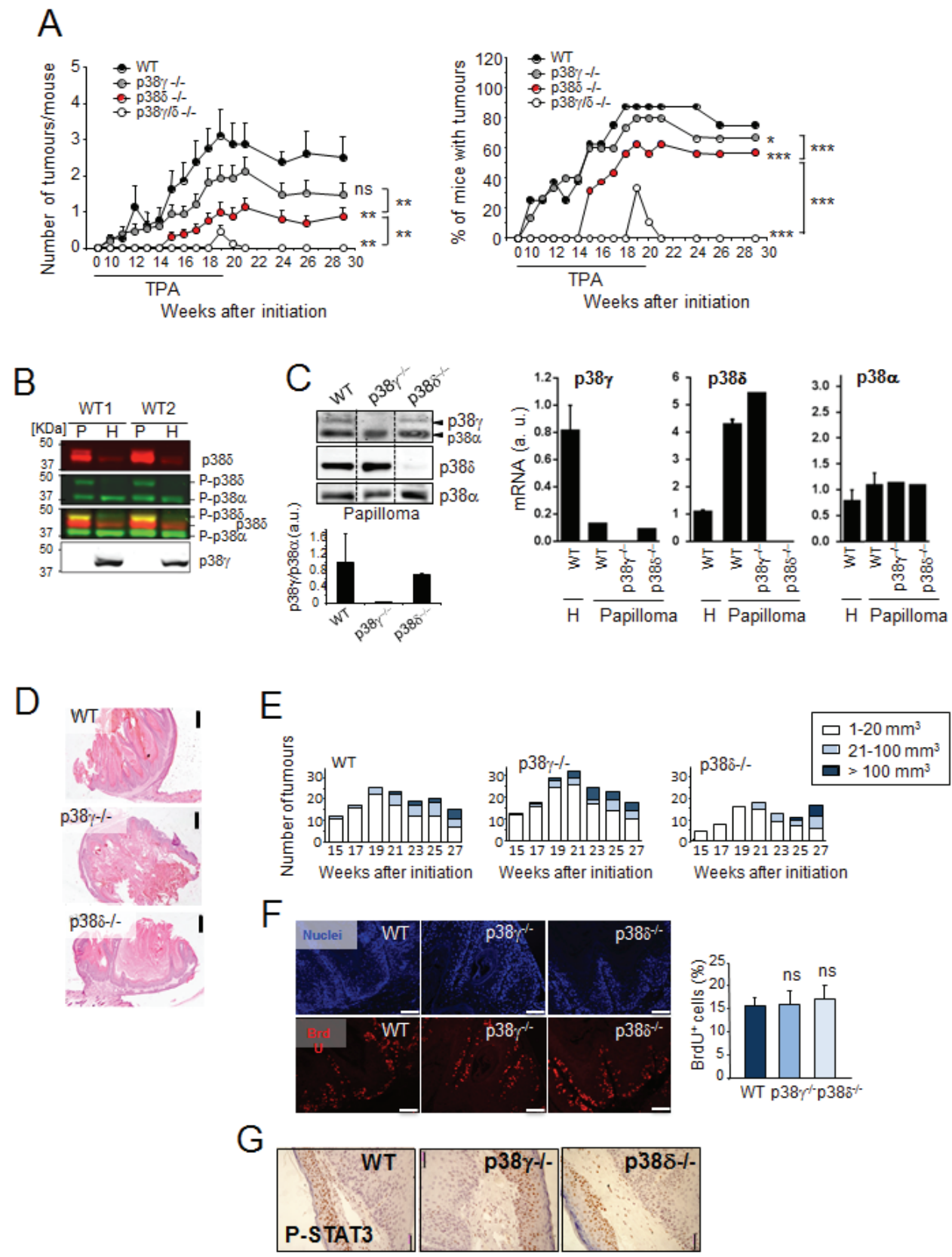

Figure 1: $\mathbf{p 3 8} \gamma / \delta$ deletion reduces the incidence of DMBA/TPA-induced skin tumour formation in mice. A. Number of tumours per mouse and percentage of mice with tumours are shown at indicated times. WT $(n=9), \mathrm{p} 38 \gamma^{-/-}(n=15), \mathrm{p} 38 \delta^{-/-}(n=16)$ and $\mathrm{p} 38 \gamma / \delta^{-\alpha}(n=9)$ mice were treated with DMBA/TPA (see Methods) and the skin was monitored for tumour growth at indicated times. Tumour number per mouse shown as mean \pm SEM. ns, not significant; $* x \leq 0.05 ; * * p \leq 0.01 ; * * * \leq 0.001$ relative to WT mice or between indicated genotypes (black lines). B. Papilloma $(\mathrm{P})$ and healthy skin $(\mathrm{H})$ protein extracts from two WT mice (WT1 and WT2) were

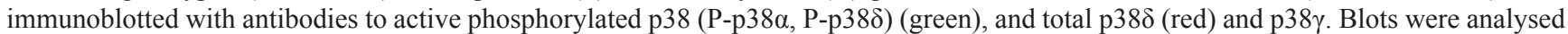
using the Odyssey infrared imaging system. P-p38 was visualised in yellow when colours were merged. Results were similar in three

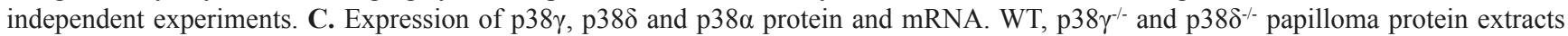
were immunoblotted with the indicated antibodies. Representative blots are shown. Band intensities from the p38 $\gamma$ and p38 $\alpha$ immunoblot were quantified using the Odyssey infrared imaging system. Quantification is represented as p38 $\gamma / \mathrm{p} 38 \alpha$. Data show mean \pm SEM. qPCR of p38MAPK mRNA in total RNA from WT, p38 $\gamma^{-/}$or $\mathrm{p} 38 \delta^{-/}$papilloma and in total RNA from healthy skin $(\mathrm{H})$ from WT mice. Expression of the different p38 mRNA was normalised to GAPDH. Data show mean \pm SEM from one representative experiment of at least three with similar results. D. Representative H\&E-stained sections of skin tumour at week 29 (Panel A). Scale bars: $500 \mu$ m. E. Histograms of tumour size distribution in A. at indicated times. F. Proliferation in tumours from WT, p38 $\gamma^{-/-}$and p $38 \delta^{-/-}$mice (at week 29) was evaluated by BrdU staining. BrdU positive cells (red) were counted and represented as percentage of total basal keratinocytes. Nuclei are Hoechst33342stained (blue). Results show mean \pm SEM ( $n=3-6$ tumours/group). ns, not significant. Scale bars: $100 \mu$ m. G. Papilloma sections were stained to evaluate P-STAT3. Scale bars: $50 \mu \mathrm{m}$. Representative sections are shown. (See Materials and Methods). 
16]. We have also confirmed the effect of the combined $\mathrm{p} 38 \gamma$ and $\mathrm{p} 38 \delta$ deletion on skin tumourigenesis in a different tumourigenic assay using the human epidermoid cancer A431 cells, which express p38 $\gamma$ and p38 (Figure 2). p38 $\gamma$ and/or p38 were stably knocked down using selective shRNA (Figure 2A). We generated tumour xenografts by subcutaneous injection of shControl-A431, shp38 $\gamma$-A431, shp38 $\delta$-A431 or shp38 $\gamma / \delta$-A431 cells into athymic nude mice. shControl-, shp38 $\gamma$ - and shp38 8 -A 431 cells formed large, rapidly growing tumours in all mice with no significant differences in tumour incidence, but knockdown of both $\mathrm{p} 38 \gamma$ and $\mathrm{p} 38 \delta$ severely decreased tumour growth (Figure 2B). Loss of p38 $\gamma$ and p38 in A431 cells thus appears sufficient to abolish tumourigenesis in vivo. These data coincide with the finding that combined deletion of $\mathrm{p} 38 \gamma$ and $\mathrm{p} 38 \delta$ impaired tumour formation in the DMBA/TPA model and confirm the redundant effect of $\mathrm{p} 38 \gamma$ and $\mathrm{p} 38 \delta$ in tumour development.

\section{DMBA-induced response in skin is not affected by loss of p38 $\gamma$ and p38}

In the murine DMBA/TPA-induced carcinogenesis model, skin tumours are initiated following treatment with the carcinogen DMBA, which causes DNA damage and induces mutations in genes such as HRas in certain target cells [28]. To determine the effect of p38 $\gamma$ and p38 deficiency on tumour initiation, we analysed two protective responses to DMBA-induced DNA damage, apoptosis induction and DNA repair. We first examined p38 $\gamma$ mRNA and protein expression in keratinocytes. In contrast to published reports [29, 30], we found $\mathrm{p} 38 \gamma$ expression of mRNA and protein in keratinocytes and skin (Figure 3A, 3B). In WT mice, p38 $\gamma$ mRNA and protein levels were lower in keratinocytes than in whole skin. p38 $\gamma$ expression was similar in skin of WT and p38 $\delta$-deficient mice, but was not detectable in $\mathrm{p} 38 \gamma^{-/-}$mice (Figure $3 \mathrm{~A}$,

\section{A}
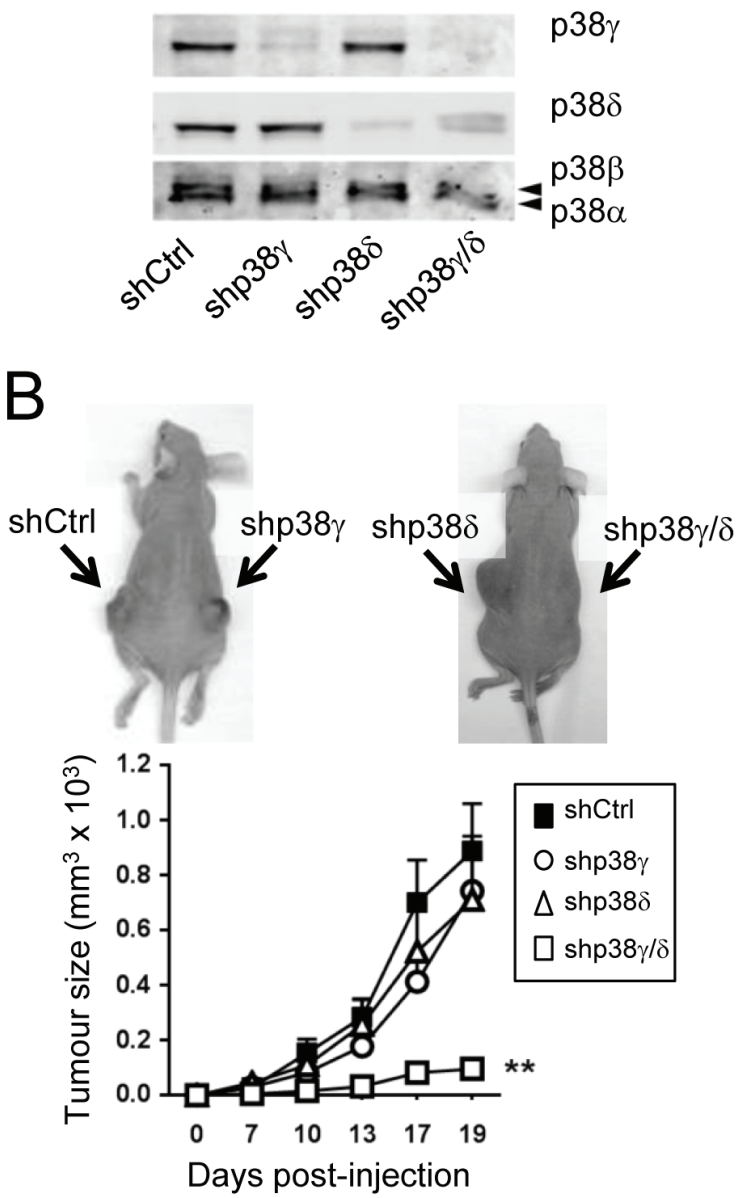

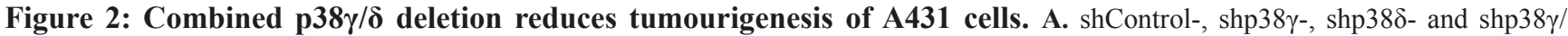
$\delta$-A431 cell extracts $(50 \mu \mathrm{g})$ were examined by immunoblotting with the indicated antibodies to determine p38 $\gamma$ and p38 $\delta$ expression.

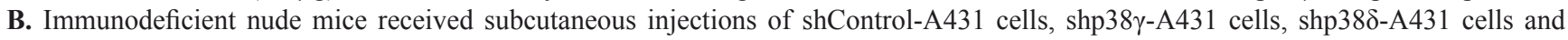
shp38 $\gamma / \delta$-A431 cells, and tumour volume was measured periodically as indicated. Values are means \pm SD for 12 mice. Inset: Representative photographs of mouse tumour at day 19. Arrows indicate injection sites. 
A

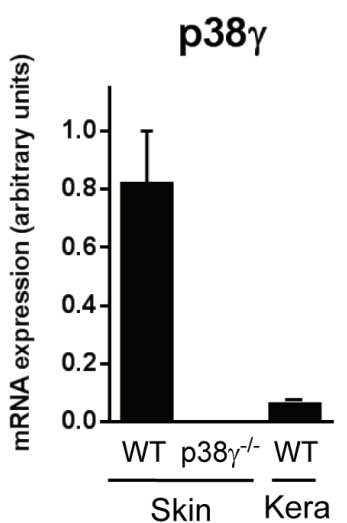

C

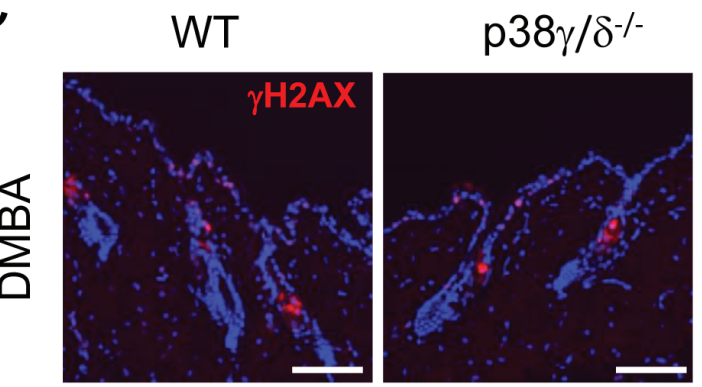

p38
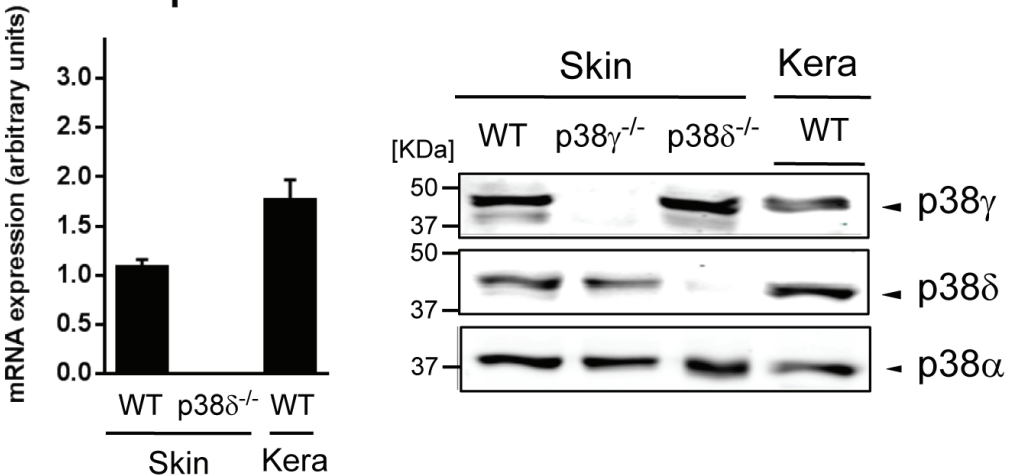

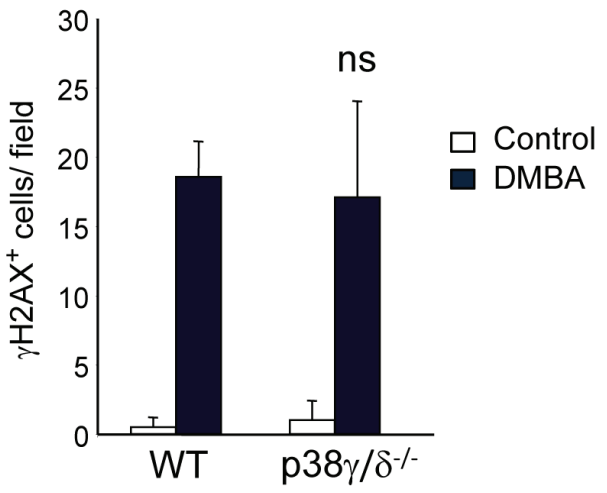

$\mathrm{D}$
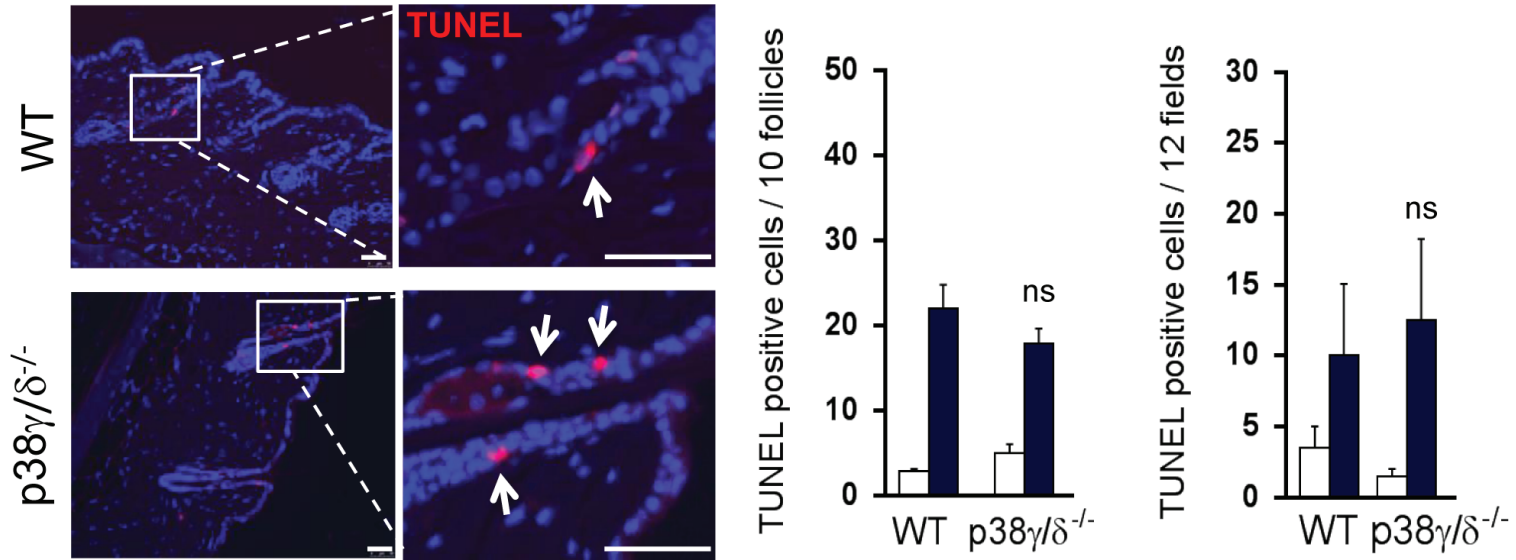

Figure 3: Combined p38 $\gamma$ and p38 $\delta$ deletion does not affect DMBA response in the skin. A. p38 $\gamma$ and p38 expression in the skin and in keratinocytes. qPCR of p38MAPK mRNA in total RNA from WT, p38 $\gamma^{-/}$or p38 $\delta^{-/}$skin and in total RNA from keratinocytes from WT mice. Expression of the different p38 mRNA was normalised to GAPDH. Data show mean \pm SEM ( $n=3$ mice/group). B. WT, $\mathrm{p} 38 \gamma^{-/}$and $\mathrm{p} 38 \delta^{-/}$skin extracts and WT keratinocytes lysates $(50 \mu \mathrm{g})$ were immunoblotted with antibodies to total p38 $\gamma, \mathrm{p} 38 \delta$ and $\mathrm{p} 38 \alpha$. Representative blots are shown. C. WT and $\mathrm{p} 38 \gamma / \delta^{-/}$mice were treated for $24 \mathrm{~h}$ with DMBA or acetone as control. Skin sections were immunofluorescence-stained to evaluate DMBA-induced DNA damage response $(\gamma \mathrm{H} 2 \mathrm{AX}) . \gamma \mathrm{H} 2 \mathrm{AX}{ }^{+}$cells (red) were quantified; at least 8 fields/mouse were scored. Results show mean $\pm \operatorname{SEM}(n=4$ mice/group). ns, not significant, relative to WT mice in the same conditions. Scale bars: $100 \mu \mathrm{m}$. D., E. Apoptosis in mouse skin was evaluated by TUNEL staining (red) at 24 h post-DMBA application. Apoptotic cells were counted; 12 fields/mouse were scored. Results show mean \pm SEM ( $n=4$ mice/group). ns, not significant, relative to WT mice. Panel D. shows quantitation of follicular apoptotic cells and E. shows interfollicular apoptotic cells. Scale bars: $50 \mu \mathrm{m}$. In C. and D. nuclei are Hoechst33342-stained (blue). 
3B). Analysis of $\mathrm{p} 38 \delta \mathrm{mRNA}$ and protein levels as control showed slightly higher expression in keratinocytes than in skin extracts in WT mice (Figure 3A, 3B), whereas it was not expressed in $\mathrm{p} 38 \delta^{-/-}$mice. p38 $\delta$ levels were similar in WT and p38 $\gamma^{-/-}$mouse skin (Figure 3A, 3B).

Phosphorylated histone $\mathrm{H} 2 \mathrm{AX}(\gamma \mathrm{H} 2 \mathrm{AX})$ is recruited to sites of double-strand DNA damage and subsequent breaks, and is upregulated following DMBA treatment. The proportion of $\gamma \mathrm{H} 2 \mathrm{AX}$-expressing epithelial cells was similar in WT and $\mathrm{p} 38 \gamma / \delta$-deficient epidermis, whether or not skin had been DMBA-treated (Figure 3C), suggesting that DNA repair was unaffected by the lack of $\mathrm{p} 38 \gamma / \delta$.

Topical DMBA application to WT and $\mathrm{p} 38 \gamma / \delta$ deficient mice resulted in a significantly increased number of epidermal cells undergoing apoptosis compared with untreated control mice. TUNEL staining revealed the majority of DMBA-induced apoptotic cells in a specific region of the hair follicles (Figure 3D), with a smaller number in the interfollicular epidermis (Figure 3E). After DMBA treatment, the distribution and number of TUNELpositive cells were similar in WT and p38 $\gamma / \delta$-deficient mouse epidermis (Figure 3D, 3E). This similar DMBA responsiveness in WT and $\mathrm{p} 38 \gamma / \delta^{-/-}$mice suggested that $\mathrm{p} 38 \gamma / \delta$ are not necessary for maintaining keratinocyte survival after DMBA-induced DNA damage at tumour initiation.

\section{Loss of p38 $\gamma$ and p38 impairs TPA-induced epidermal proliferation}

TPA induces a proliferative response in mouse epidermis, necessary for the clonal expansion of mutated cells to form precancerous lesions (i.e., papillomas) [31]. To examine epidermal proliferation in vivo, we treated WT and $\mathrm{p} 38 \gamma / \delta^{--}$mouse skin with a single dose of TPA. We observed no difference in untreated skin histological structure in these mice regardless of genetic background, which suggests that $\mathrm{p} 38 \gamma$ and $\mathrm{p} 38 \delta$ are not necessary for skin homeostasis (Figure 4A). TPA treatment induced a notable increase in epidermal thickness (hyperplasia) in WT mice that was significantly attenuated in $\mathrm{p} 38 \gamma / \delta^{-/-}$ mice (Figure 4A). p38 $\gamma / \delta$-deficient mice also showed a significant reduction in epidermal cell proliferation compared to WT mice, as demonstrated by BrdU incorporation following TPA application (Figure 4B). Epithelial proliferation was lower in $\mathrm{p} 38 \gamma^{-/-}$and $\mathrm{p} 38 \delta^{-/-}$ compared to WT mice (Figure 4A, 4B), while the decrease in skin proliferation was greater in $\mathrm{p} 38 \gamma / \delta^{-/-}$mice than in other genotypes; this indicates that functional p38 $\gamma$ and p38 kinases are needed for TPA-induced epidermal hyperproliferation.

The mouse skin response to topical TPA application

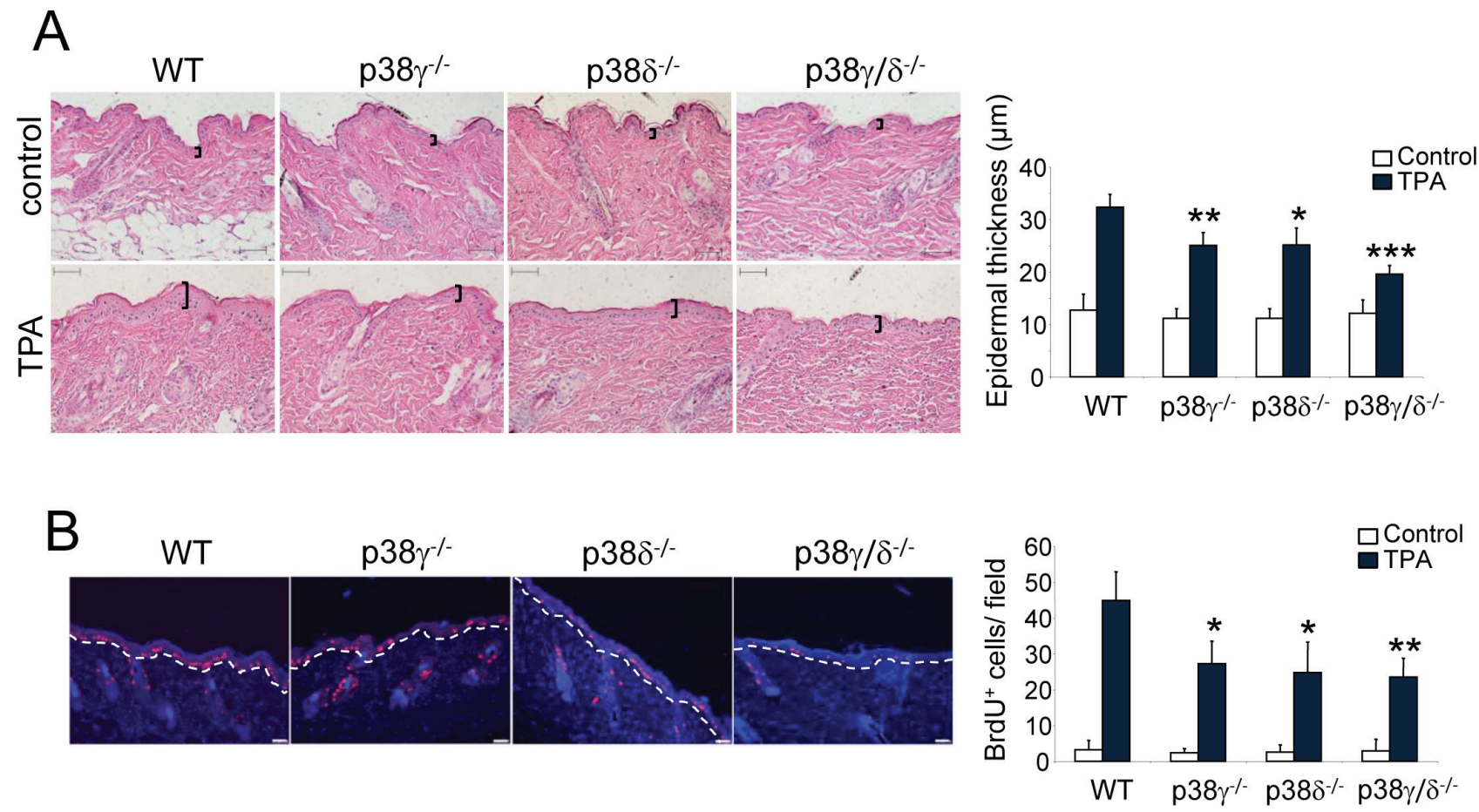

Figure 4: p38 $\gamma$ and $\mathbf{p 3 8} \delta$ deletion decreases epithelial cell proliferation. A. Representative H\&E staining of skin sections from WT, p38 $\gamma^{--}, \mathrm{p} 38 \delta^{-/-}$and $\mathrm{p} 38 \gamma / \delta^{-/-}$mice treated for $31 \mathrm{~h}$ with TPA or acetone as control. Epidermal thickness, indicated by black lines, was measured. Results show mean $\pm \operatorname{SEM}\left(n=4\right.$ mice/group), ${ }^{*} p \leq 0.05 ; * * p \leq 0.01 ; * * * p 0.001$. Scale bars: $100 \mu \mathrm{m}$. B. Proliferation in skin of WT, p38 $\gamma^{-/}, \mathrm{p} 38 \delta^{-/-}$and $\mathrm{p} 38 \gamma / \delta^{-/-}$mice was evaluated by BrdU staining at $31 \mathrm{~h}$ post-TPA application. BrdU positive cells (red) were counted; 12 fields/mouse were usually scored. Nuclei are Hoechst33342-stained (blue). Results show mean $\pm \operatorname{SEM}\left(n=4\right.$ mice/group). ${ }^{*} p$ $\leq 0.05 ; * *<0.01$, relative to WT mice. Scale bars: $50 \mu \mathrm{m}$. 
is associated with activation of several intracellular signalling pathways such as p38 $2 \mathrm{MAPK}$, which has been implicated in regulating mouse keratinocyte proliferation. To evaluate TPA-mediated activation of p38 $\gamma$ and $\mathrm{p} 38 \delta$, we analysed p38MAPK phosphorylation in skin extracts at various times after TPA treatment by immunoblot. In response to TPA, p38 $\gamma$ and $\mathrm{p} 38 \delta$ were activated in WT but not in $\mathrm{p} 38 \gamma / \delta$-deficient mouse skin (Figure $5 \mathrm{~A}, 5 \mathrm{~B}$ ). We also compared $\mathrm{p} 38 \mathrm{MAPK}$ activation in $\mathrm{p} 38 \gamma^{-/}$and $\mathrm{p} 38 \delta^{-}$ / single knockouts to WT mice. p38 $\alpha$ was activated to the same extent in all genotypes (Figure 5C). In contrast to $\mathrm{p} 38 \delta$, which was activated in $\mathrm{p} 38 \gamma^{-/-}$mice (Figure 5D), p38 $\gamma$ activation was markedly reduced in $\mathrm{p} 38 \delta^{-/-}$mice compared to WT mouse skin at all TPA treatment times (Figure 5C, 5E), indicating that $\mathrm{p} 38 \delta$ regulates $\mathrm{p} 38 \gamma$ activation in skin.

TPA treatment activated all three major MAPK pathways, JNK, p38 $\alpha$, and ERK1/2, as well as the canonical NF $\kappa \mathrm{B}$ signalling pathway to the same extent in WT and $\mathrm{p} 38 \gamma / \delta$-deficient mice (Figure $5 \mathrm{~F}$ ), showing that both genotypes respond to TPA treatment. TPA-induced phosphorylation of STAT3 was nonetheless significantly reduced in $\mathrm{p} 38 \gamma / \delta^{-/-}$compared to WT mice (Figure $5 \mathrm{G}$ ). STAT3 activation in $\mathrm{p} 38 \gamma^{-/}, \mathrm{p} 38 \delta^{-/-}$and WT mice was similar (Figure S2). These data show that $\mathrm{p} 38 \gamma / \delta$ has a function in TPA-treated murine keratinocyte proliferation, at least in part by controlling STAT3 activation.

\section{$\mathrm{p} 38 \mathrm{\gamma} / \mathrm{\delta}$ deficiency reduces TPA-induced skin inflammation in vivo}

Since tumour induction in the DMBA/TPA model depends on proinflammatory processes [26], it was important to determine whether or not $\mathrm{p} 38 \gamma$ and $\mathrm{p} 38 \delta$ regulate skin inflammation. Topical TPA application on mouse skin induces local inflammation and triggers strong upregulation of proinflammatory mediators such as cytokines and chemokines, leading to dermal infiltration by immune cells [31]. To test whether $\mathrm{p} 38 \gamma / \delta$ deficiency affects the TPA-induced inflammatory response, we used total skin extracts from TPA-treated mice to study the expression kinetics of proinflammatory genes central to skin carcinogenesis. qPCR analysis showed impaired production of $I L-6, I L-1 \beta$ and $T N F \alpha$ mRNA in $\mathrm{p} 38 \gamma / \delta$ deficient compared to WT mice (Figure 6A). p38 $\gamma / \delta$ deficiency did not alter $T G F-\beta$ mRNA production (Figure $\mathrm{S} 3 \mathrm{~A})$. Neither $\mathrm{p} 38 \gamma$ nor $\mathrm{p} 38 \delta$ deficiency significantly affected TPA-induced cytokine production (Figure S3B), supporting the idea that $\mathrm{p} 38 \gamma$ and $\mathrm{p} 38 \delta$ functions are partially redundant. Using Mouse Cytokine Array Panel to test cytokine expression, we found that at $8 \mathrm{~h}$ post-TPA treatment IL- 6 and IL- $1 \beta$ proteins were expressed by WT and $\mathrm{p} 38 \gamma / \delta$-deficient mice, whereas $\mathrm{TNF} \alpha$ protein was hardly detectable. Moreover, the expression levels of both interleukins in $\mathrm{p} 38 \gamma / \delta$-deficient mice were lower than in
WT (Figure 6B). At $24 \mathrm{~h}$ post-TPA treatment, we found IL-1 $\beta$ and TNF $\alpha$ production, but not IL-6 (Figure 6B). Expression of TNF $\alpha$ but not of IL-1 $\beta$ was impaired in p38 $\gamma / \delta$-deficient mice at that time (Figure 6B).

The mRNA expression of chemokines implicated in neutrophil and macrophage migration, such as $K C$ (CXCL1) and MIP-2 (CXCL2) [32], was higher in TPAtreated skin of WT than of $\mathrm{p} 38 \gamma / \delta^{-/-}$mice (Figure $6 \mathrm{~A}$ ). $\mathrm{p} 38 \gamma / \delta$ also regulated chemokine protein expression; at $8 \mathrm{~h}$ and $24 \mathrm{~h}$ post-TPA treatment, p38 $\gamma / \delta$-deficient mice expressed lower levels of KC and MIP-2 than WT mice (Figure 6B). Mouse Cytokine Array Panel-based analysis showed other TPA-induced chemokines and cytokines that are regulated by $\mathrm{p} 38 \gamma / \delta$ (Figure S3C). These results confirm the need of $\mathrm{p} 38 \gamma$ and $\mathrm{p} 38 \delta$ for cytokine production in the inflammatory response.

To determine whether the observed differences in cytokine and chemokine levels were attributable to the reported effects of $\mathrm{p} 38 \gamma / \delta$ in myeloid cells $[14,17]$, we analysed their expression in mice bearing combined myeloid cell-specific deletion of p38 $\gamma$ and $\mathrm{p} 38 \delta$ (Figure $\mathrm{S} 4 \mathrm{~A})$. In contrast to our findings in $\mathrm{p} 38 \gamma / \delta$-deficient mice, we observed no differences in cytokine or chemokine mRNA production between TPA-treated WT and LysMCrep38 $\gamma / \delta^{-/-}$mice (Figure S4B), indicating that ablation of $\mathrm{p} 38 \gamma$ and $\mathrm{p} 38 \delta$ in myeloid cells does not affect production of inflammatory mediators during TPA-induced skin inflammation.

Keratinocytes constitutively secrete or are induced to release cytokines such as IL-6 or IL-1 $\beta$, and chemokines such as KC (CXCL1) [33]. We studied mRNA levels of various inflammatory mediators in cultured mouse keratinocytes. TPA induced the expression of $I L-6, K C$, $M I P-2$ (CXCL2) and TGF- $\beta$ mRNA (Figure 6C); we did not observe $I L-1 \beta$ induction in these conditions (Figure 6C). Compared to WT keratinocytes, lack of $\mathrm{p} 38 \gamma / \delta$ had a distinct effect on mRNA synthesis; $I L-6, I L-1 \beta$ and $K C$ mRNA synthesis was impaired, whereas $M I P-2$ and $T G F-\beta$ mRNA levels were unaffected in response to TPA (Figure 6C). These results show that $\mathrm{p} 38 \gamma$ and $\mathrm{p} 38 \delta$ in skin keratinocytes regulate production of proinflammatory molecules in response to TPA.

\section{p38 $\gamma$ and $p 38 \delta$ control TPA-induced neutrophil infiltration in skin}

Since we found defective chemokine production in p38 $\gamma / \delta$-deficient mice, we analysed immune cell infiltration in WT and $\mathrm{p} 38 \gamma / \delta^{-/-}$mouse skin. Flow cytometry (FACS) analyses in skin homogenates from WT and $\mathrm{p} 38 \gamma / \delta^{-/-}$mice showed significant changes in total leukocyte infiltration, determined as $\mathrm{CD}^{+} 5^{+}$cells, with increased leukocyte infiltrates in WT compared to $\mathrm{p} 38 \gamma / \delta^{-/}$mouse skin (Figure 7A). While there were no differences between genotypes in the accumulation of $\mathrm{CD}^{+}, \gamma \delta \mathrm{T}$ or $\mathrm{F} 4 / 80^{+}$cells (Figure 

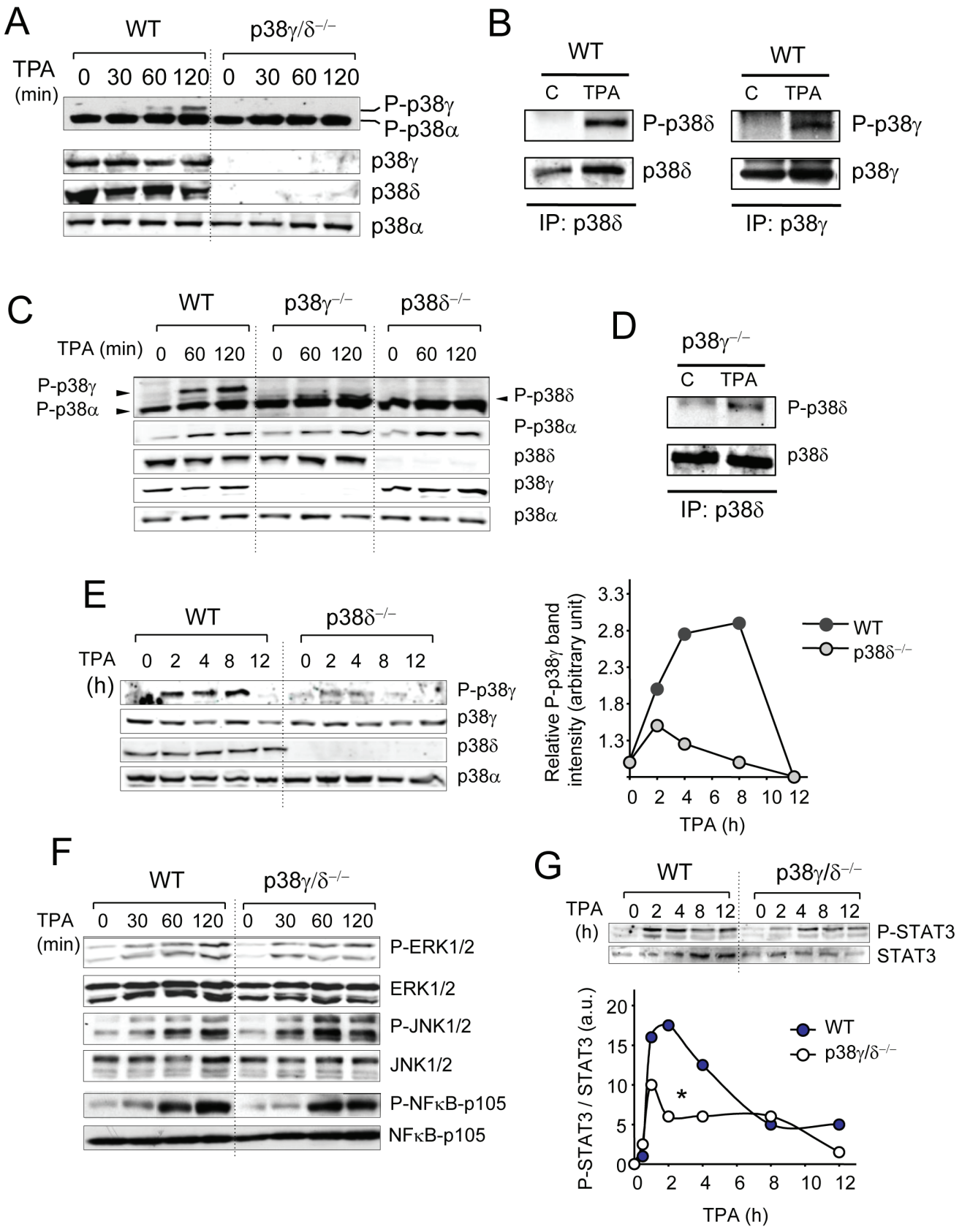

Figure 5: Activation of intracellular signalling pathways by TPA. A. Skin extracts $(50 \mu \mathrm{g})$ from WT and $\mathrm{p} 38 \gamma / \delta^{-/-}$mice, treated with acetone (control, time 0 ) or with TPA for the indicated times, were immunoblotted with antibodies to active phosphorylated p38

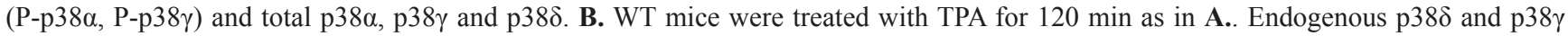
were immunoprecipitated from WT skin extracts $(2 \mathrm{mg})$. Pellets were immunoblotted with anti-P-p38 (P-p38, $\mathrm{P}-\mathrm{p} 38 \gamma)$ or -p38 $\delta$ and -p38 $\gamma$ antibodies. Representative blots are shown. C. Skin protein extracts $(50 \mu \mathrm{g})$ from WT, p38 $\gamma^{-/-}$and $\mathrm{p} 38 \delta^{-/-}$treated with TPA for the

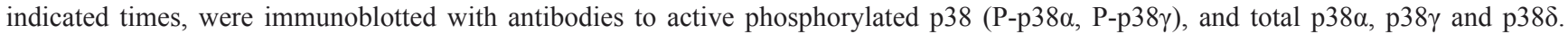
Results were similar in three independent experiments. D. p38 $\gamma^{-/-}$mice were treated with TPA for 120 min as in C.. Endogenous p38 $\delta$ was immunoprecipitated from skin extracts $(2 \mathrm{mg})$. Pellets were immunoblotted with anti-P-p38 (P-p38 $)$ or -p38 $\delta$ antibodies. Representative blots are shown. E. Skin protein extracts $(50 \mu \mathrm{g})$ from WT and $\mathrm{p} 38 \delta^{-/-}$mice, treated with TPA for the indicated times, were immunoblotted with antibodies as in C. Bands from the immunoblots were quantified using the Odyssey infrared imaging system. Quantification is represented as P-p38 $\gamma / \mathrm{p} 38 \gamma$. Data show mean \pm SEM. F. WT and p38 $\gamma / \delta^{-/}$mouse skin were treated as in A.. Skin extracts $(50 \mu \mathrm{g}) \mathrm{were}$ immunoblotted with antibodies to active phosphorylated ERK1/2 (P-ERK1/2), active phosphorylated JNK1/2 (P-JNK1/2) or phosphorylated

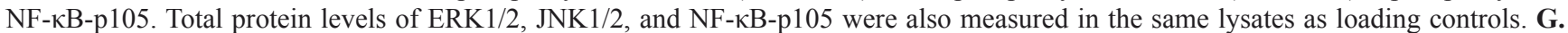
Skin extracts $(50 \mu \mathrm{g})$ from control and TPA-treated WT and $\mathrm{p} 38 \gamma / \delta^{-/}$mice were immunoblotted with antibodies to phospho- and total STAT3. Representative blots are shown. Bands were quantified using the Odyssey infrared imaging system. Quantification is represented as densities ratio P-STAT3 /STAT3. * $p \leq 0.05$. 
A
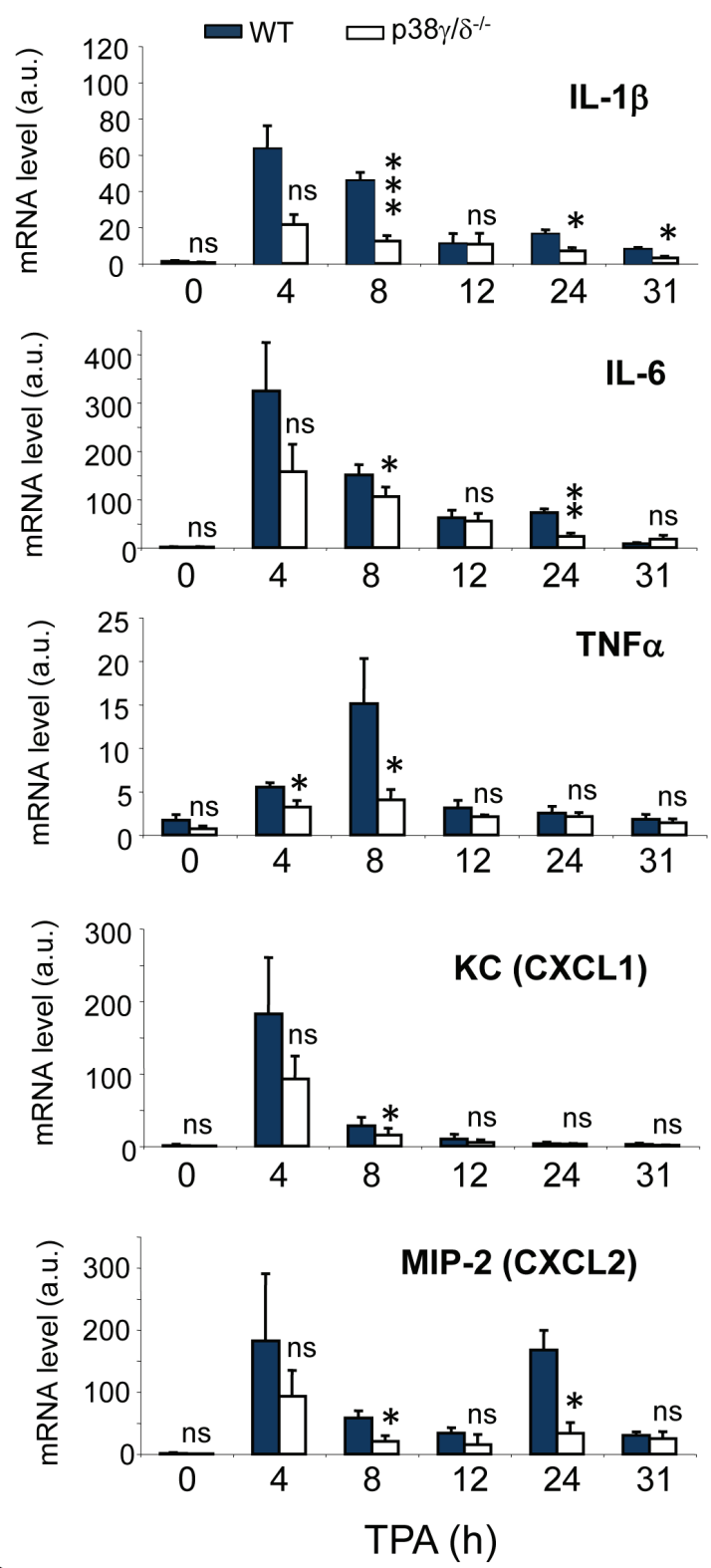

B
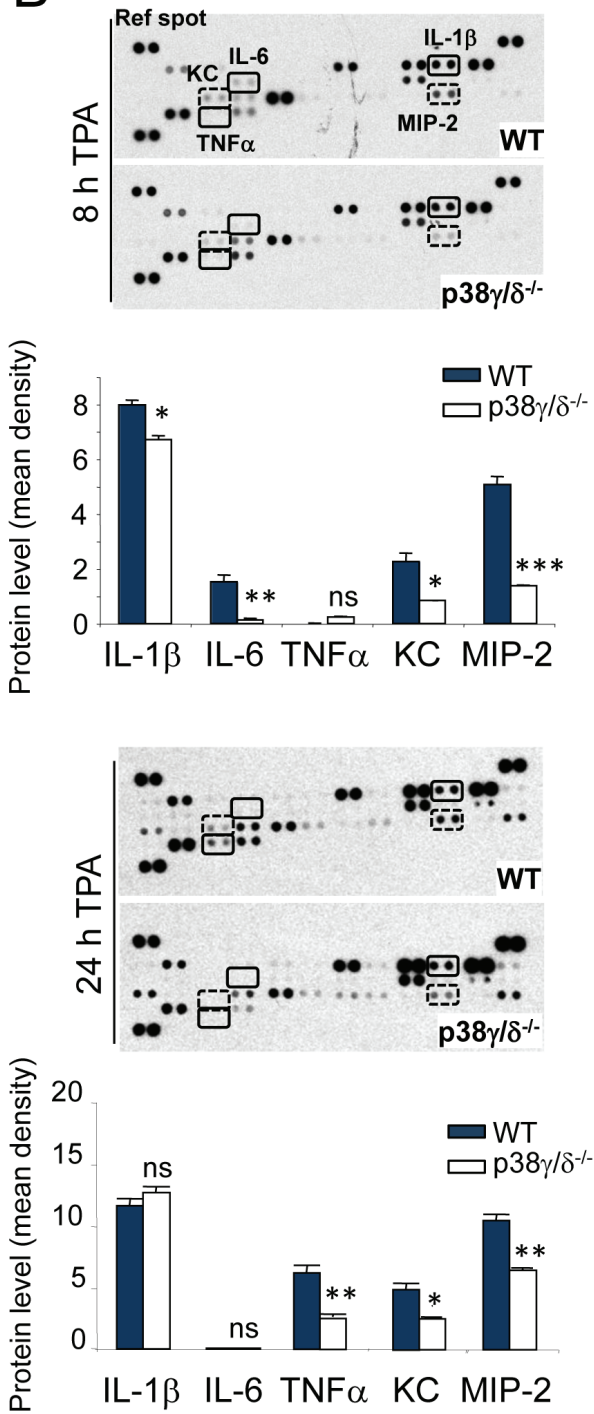

C

IL-6
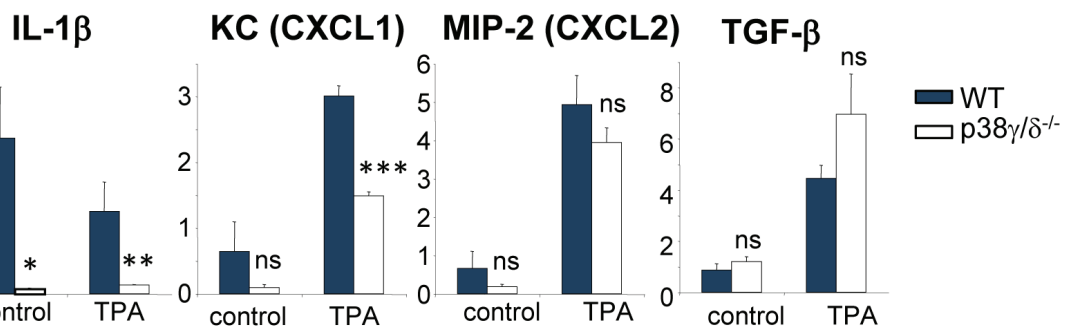

Figure 6: $\mathrm{p38} \gamma / \delta$ deletion reduces TPA-induced cytokine and chemokine production in mouse skin. A. Relative mRNA expression of indicated genes at different times was determined by qPCR in TPA-treated WT and $\mathrm{p} 38 \gamma / \delta^{-/}$mouse skin and normalised to GAPDH mRNA. Data show mean $\pm \operatorname{SEM}(n=3-6)$. ns, not significant; ${ }^{*} p \leq 0.05 ; * * p \leq 0.01, * * * p \leq 0.001$, relative to WT mice in the same conditions. B. Skin protein extracts from three WT and three p $38 \gamma / \delta^{-/-}$mice (300 $\mu \mathrm{g}$ total), treated with TPA for 8 (top) and $24 \mathrm{~h}$ (bottom), were mixed with an antibody mixture and incubated with the Mouse Cytokine Array Panel A membrane as indicated by the manufacturer (R\&D Systems). Pixel densities on the film were analysed using ImageJ software. ns, not significant; ${ }^{*} p \leq 0.05 ; * * p \leq 0.01, * * * p \leq 0.001$. C. Relative mRNA expression was determined by qPCR for indicated genes in TPA-treated WT and $\mathrm{p} 38 \gamma / \delta^{-/}$keratinocytes and normalised to GAPDH mRNA. In panel B. and C. data show mean $\pm \operatorname{SEM}(n=3)$. ns, not significant; ${ }^{*} p \leq 0.05 ; * * p \leq 0.01$, ${ }^{* * *} p \leq 0.001$, relative to WT in the same conditions. 


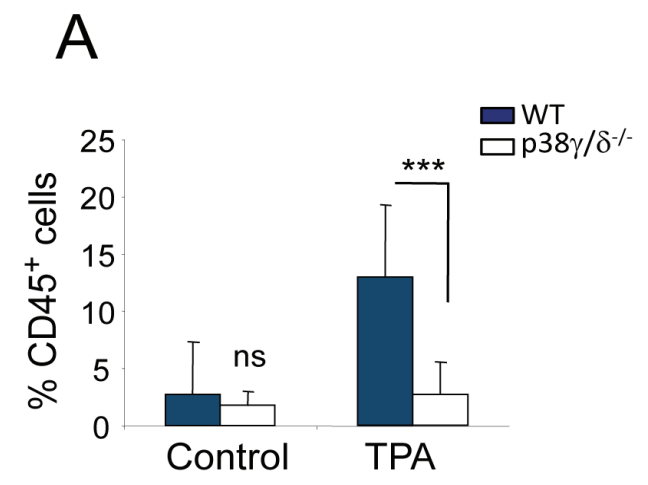

B

C

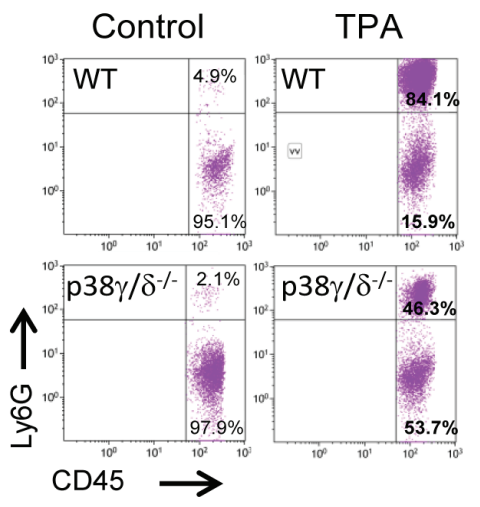

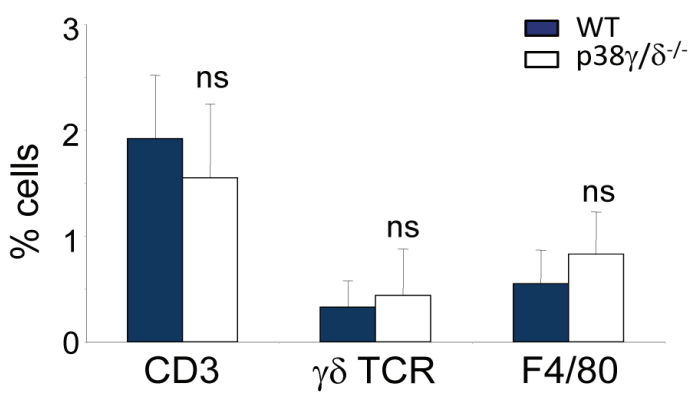
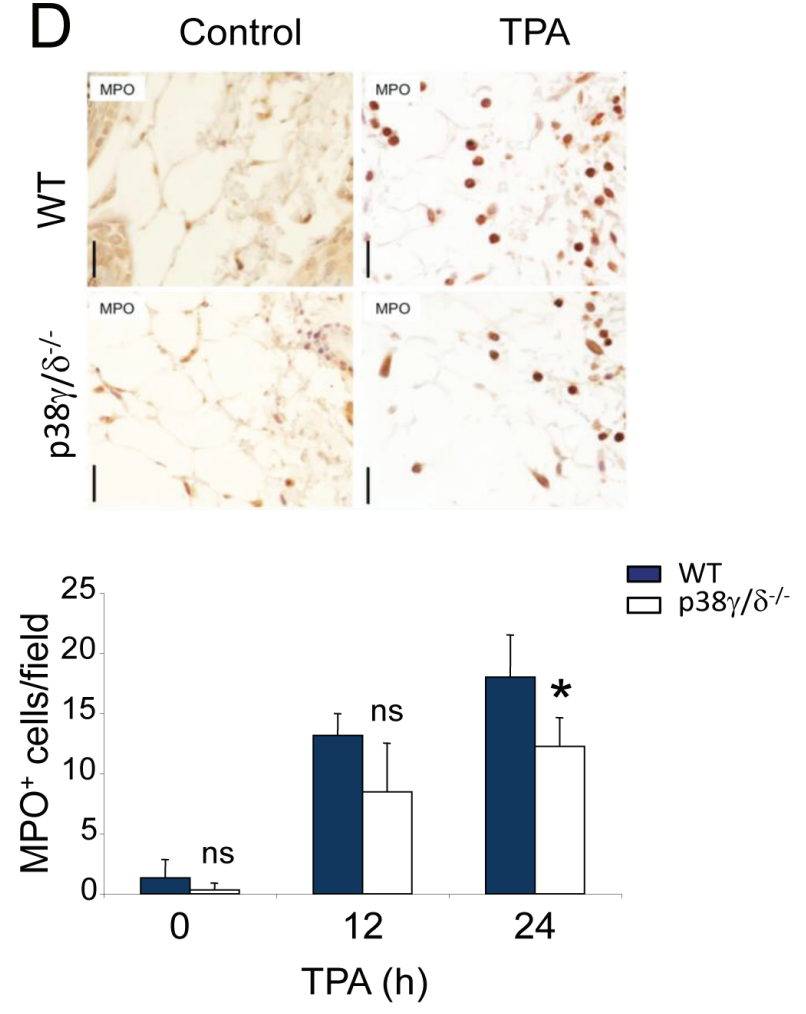

$E$

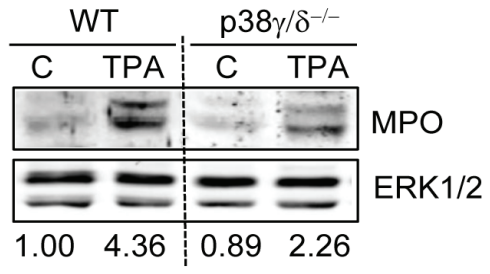

Figure 7: Reduced neutrophil recruitment in $\mathbf{p 3 8} \gamma / \mathbf{s}^{-/ 2}$ mice. A.-C. Skin cells from 24-h TPA-treated (or acetone as control) WT and $\mathrm{p} 38 \gamma / \delta^{-/}$mice were stained with anti-CD45, $-\mathrm{CD} 3,-\gamma \delta \mathrm{TCR},-\mathrm{F} 4 / 80$ and $-\mathrm{Ly} 6 \mathrm{G}$ antibodies. A. Percentages of CD45 cells are shown. $\mathrm{CD}^{2} 5^{+}$cells were gated and percentages of $\mathbf{B} . \mathrm{CD}^{+}, \gamma \delta \mathrm{TCR}^{+}$and $\mathrm{F} 4 / 80^{+}$cells, or $\mathbf{C}$. Ly $6 \mathrm{G}^{+}$cells were analysed by flow cytometry. Data show mean $\pm \operatorname{SEM}\left(n=3-4\right.$ per experiment and condition); ${ }^{* *} p \leq 0.01,{ }^{* * *} p \leq 0.001$, ns, not significant. Representative profiles are shown

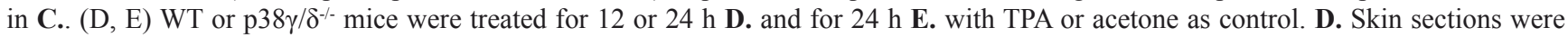
immunohistochemically stained to evaluate neutrophils (MPO). $\mathrm{MPO}^{+}$cells were quantified; 30 fields/mouse were usually scored. Results show mean $\pm \operatorname{SEM}\left(n=3\right.$ mice/group). ${ }^{*} p \leq 0.05$; ns, not significant; Scale bars: $20 \mu \mathrm{m}$. E. WT and p38 $8 / \delta^{-/-}$skin lysates $(50 \mu \mathrm{g})$ were immunoblotted with antibodies to MPO and ERK1/2 (loading control). Immunoblots were quantified using the Odyssey infrared imaging system; normalised MPO band densities are represented numerically below the blot. 
7B), there was a clear decrease in the infiltration of $\mathrm{Ly}_{6 \mathrm{G}} \mathrm{G}^{+}$ cells (neutrophil) in $\mathrm{p} 38 \gamma / \delta^{-/}$compared to WT mice (Figure 7C), consistent with reduced inflammation in the double knockout mice. Immunohistochemical analysis by myeloperoxidase (MPO) staining showed that: (i) neutrophil infiltration increased in TPA-treated $\mathrm{p} 38 \gamma / \delta^{-/-}$ and WT mice compared with vehicle-treated mice (at both 12 and $24 \mathrm{~h}$ post-treatment), and that (ii) $24 \mathrm{~h}$ after TPA, the recruitment of neutrophils to the skin was significantly lower in $\mathrm{p} 38 \gamma / \delta^{-/-}$compared to WT mice (Figure 7D). Consistent with these results, immunoblot analysis of skin extracts confirmed a decrease in MPO expression in $\mathrm{p} 38 \gamma / \delta^{-/-}$mice compared to WT (Figure 7E). Moreover, we confirmed by immunohistochemistry that there were no significant differences in $\mathrm{CD}^{+}$lymphocyte infiltration between $\mathrm{p} 38 \gamma / \delta^{-/-}$and WT mice after TPA treatment (Figure S5). These observations suggest that $\mathrm{p} 38 \gamma$ and p38 $\delta$ are endogenous promoters of skin inflammation, and that they modulate the pro-carcinogenic local environment and inflammation in DMBA/TPA-induced skin cancer.

\section{DISCUSSION}

In this study we addressed the role of $\mathrm{p} 38 \gamma$ and $\mathrm{p} 38 \delta$ kinases in skin carcinogenesis and skin inflammation. In agreement with previous results [24, 34-36] we confirmed that $\mathrm{p} 38 \delta$ expression is high in skin and in keratinocytes. Here we show that p38 $\gamma$ is poorly expressed in keratinocytes, which is probably the reason why its function in skin has so far been ignored. The role of $\mathrm{p} 38 \gamma$ in skin carcinogenesis has not been addressed either; in contrast, a role for $\mathrm{p} 38 \delta$ in skin tumour formation has been described [24]. p38 deficiency has been shown to reduce tumour formation in the chemical DMBA/TPA model, which was accompanied by a decrease in proliferation in the epidermis [24]. We examined the effect of the deletion of $\mathrm{p} 38 \gamma, \mathrm{p} 38 \delta$ or both in the DMBA/TPA-induced skin tumourigenesis model and found that $\mathrm{p} 38 \gamma / \delta$-deficient mice are strikingly resistant to tumour development. Lack of $\mathrm{p} 38 \gamma$ or $\mathrm{p} 38 \delta$ alone also led to a reduction in tumour incidence, although it was smaller than in $\mathrm{p} 38 \gamma / \delta^{-/-}$mice. The findings that only p38 $\delta$ was phosphorylated in skin tumours and that $\mathrm{p} 38 \delta$ deletion caused a more pronounced resistance to tumour development than the lack of $\mathrm{p} 38 \gamma$ alone indicate a predominant role for $\mathrm{p} 38 \delta$ in regulating skin tumour formation. Deletion of the two p38MAPK isoforms, $\mathrm{p} 38 \gamma$ and $\mathrm{p} 38 \delta$, exerted a much more protective effect against tumour formation, thereby highlighting that p38 $\gamma$ is also important in this model. Interestingly, we found that $\mathrm{p} 38 \gamma$ phosphorylation was impaired in TPAstimulated $\mathrm{p} 38 \delta^{-/-}$mouse skin compared to WT, therefore some effects observed in $\mathrm{p} 38 \delta^{-/-}$mice could be due to the reduced $\mathrm{p} 38 \gamma$ activation.

$\mathrm{p} 38 \delta^{-/-}$and $\mathrm{p} 38 \gamma / \delta^{-/-}$phenotypes were not exactly the same in the DMBA/TPA model despite the severe reduction of $\mathrm{p} 38 \gamma$ activity in mice lacking $\mathrm{p} 38 \delta$. This could be due to the residual activity of $\mathrm{p} 38 \gamma$ in the $\mathrm{p} 38 \delta$ - mouse skin, sufficient to compensate the lack of p38 and modulate skin carcinogenesis. Another explanation is that $\mathrm{p} 38 \gamma$ might regulate tumour formation through a mechanism independent of its phosphorylation and activation, which is consistent with previous results showing that $\mathrm{p} 38 \gamma$ has a function independent of its catalytic activity regulating protein-protein and proteinmRNA complexes [37], and in K-Ras transformation of IEC-6 cells [38]. In contrast with the previous study by Schindler et al. [24], where p38 deletion decreased cell proliferation and STAT-3 phosphorylation in papillomas, our results show that the $\mathrm{p} 38 \delta^{-/-}$and WT tumours displayed similar basal cell proliferation and STAT3 phosphorylation. These contradicting results could be explained by differences in the DMBA/TPA protocol used in the two studies. We analyzed the tumours 10 weeks after the TPA treatment had finished, whereas in Schindler et al. the analysis was performed in samples of skin tumours undergoing TPA-induced growth.

The DMBA/TPA two-stage carcinogenesis model recapitulates the important concept that tumour development is a multi-step process (tumour initiation, promotion and progression) and also depends on proinflammatory processes having a large inflammatory component [26]. Analysis of the mechanisms of $\mathrm{p} 38 \gamma / \delta$ action indicates that, in the DMBA/TPA model, these kinases act on early tumour promotion. Our data indicate that the reduced tumour formation in $\mathrm{p} 38 \gamma / \delta$-deficient mice was not due to effects in DMBA-induced initiation, and suggest that the $\mathrm{p} 38 \gamma$ and $\mathrm{p} 38 \delta$ pathways modulate promotion of epithelial carcinogenesis. Epithelial cell hyperproliferation in TPA-treated skin is impaired in p38 $/ \delta$-deficient mice, accompanied by a reduction in activation of the oncogenic transcription factor STAT3, which is associated with cell proliferation and skin tumour formation [39].

The $\mathrm{p} 38 \gamma$ and $\mathrm{p} 38 \delta$ pathways can also promote epithelial carcinogenesis by regulating proinflammatory cytokine and chemokine production; inflammatory pathways maintain the survival and growth of epithelial cells with genomic alterations during tumour promotion [40]. Comparison of $\mathrm{p} 38 \gamma / \delta^{-/-}$and WT mice showed alterations in the innate immune response, important for initiation of inflammation. Production of proinflammatory mediators such as the cytokines TNF $\alpha$, IL-1 $\beta$ and IL- 6 and the chemokines KC and MIP-2 was lower in $\mathrm{p} 38 \gamma / \delta^{-/-}$mice in response to TPA. Neither p38 $\gamma$ nor p38 deficiency, alone, affects the production of inflammatory mediators, indicating that $\mathrm{p} 38 \gamma$ and $\mathrm{p} 38 \delta$ have redundant function, which is in line with previous results from in vivo septic shock, collagen-induced arthritis and colitis models [1416]. Further studies are needed to determine the molecular mechanism by which $\mathrm{p} 38 \gamma$ and $\mathrm{p} 38 \delta$ collaborate in the control of the production of inflammatory mediators. We hypothesize that both kinases could directly modulate the 
transcription of determined cytokines and the expression of components of other signalling pathways essential for cytokine production. For example, p38 $\gamma$ and p $38 \delta$ regulate the protein expression levels of the kinase TPL2, which is upstream of MKK1-ERK1/2 and is necessary for cytokine production in response to LPS in macrophages and dendritic cells [14].

It is likely that $\mathrm{p} 38 \gamma / \delta$ regulate epithelial cell proliferation by modulating skin inflammation. IL-6 activates STAT3 [39] and might therefore induce cell proliferation. Moreover, there is evidence that IL-6 and STAT3 signalling are important for the proliferation of tumour cells in mouse colon cancer models [41]. Other cytokines expressed by keratinocytes such as IL-1 $\beta$ also modulate their own proliferation by enhancing expression of certain growth factors in fibroblasts [42]. TNF $\alpha$, whose expression is reduced in $\mathrm{p} 38 \gamma / \delta^{-/-}$mice, is involved in the progression of different tumours, including chemically induced squamous cancers, and could then mediate the effects of $\mathrm{p} 38 \gamma / \delta$ deletion. It has been shown that TNF $\alpha$ deficient mice are largely resistant to tumour formation in the DMBA/TPA model $[43,44]$.

Cutaneous activation by TPA results in secretion of chemoattractants that recruit neutrophils and other inflammatory cells, that contribute to the sustained hyperplasia associated with tumour promotion [45]. The number of neutrophils recruited to skin during TPA-induced inflammation, as well as the levels of the neutrophil chemoattractants KC and MIP-2, were considerably lower in $\mathrm{p} 38 \gamma / \delta^{-/-}$than in WT mice. In contrast, $\mathrm{p} 38 \gamma / \delta$ deficiency did not affect macrophage or $\mathrm{T}$ cell infiltration. Although the precise role of neutrophils in tumour development has not yet been clearly established, their infiltration into skin is correlated with skin carcinogenesis. Elimination of $\mathrm{Gr}-1^{+}$leukocytes in athymic nude mice slowed the growth of a variant of a UV light-induced tumour [46], and DMBA/TPA-treated mice that lack CXCR2, the chemokine receptor for $\mathrm{KC}$ and MIP-2, showed a reduced neutrophil chemotaxis and resistance to skin tumourigenesis [47]. We found that reduced neutrophil recruitment in the TPA-treated skin of the $\mathrm{p} 38 \gamma / \delta^{-/-}$mice correlates with protection from tumour growth. Although it has been shown that $\mathrm{p} 38 \delta$ in neutrophils is required for their migration to inflammatory sites [48], it is likely that in our study neutrophils are drawn into the inflamed skin by the common neutrophil chemoattractants $\mathrm{KC}$ and MIP-2, as their expression is higher in WT than in $\mathrm{p} 38 \gamma / \delta^{-/}$keratinocytes and skin. This is supported by our previous results in a colitis-associated colon cancer (CAC) model, in which cytokine/chemokine production, neutrophil recruitment and tumour formation in $\mathrm{p} 38 \gamma / \delta$-deficient mice were reduced compared to WT mice [16]. Interestingly, in the CAC model, p38 $\gamma / \delta$ regulate cytokine production in hematopoietic cells [16], whereas in the DMBA/TPA skin carcinogenesis model p $38 \gamma / \delta$ in keratinocytes seem to have a predominant role modulating the cytokine production; however, further analysis needs to be performed to clarify this difference.

In summary, our study emphasises an important role of the $\mathrm{p} 38 \gamma / \delta$ pathway in promoting epithelial carcinogenesis. Therapies that target $\mathrm{p} 38 \gamma$ and $\mathrm{p} 38 \delta$ might be of interest as a potential approach to carcinogenesis inhibition. We suggest that $\mathrm{p} 38 \gamma / \delta$ control skin tumour development by supporting proliferation and inflammation in the promotion phase of DMBA/TPA-induced carcinogenesis, and propose key pro-inflammatory mediators and cytokines as p $38 \gamma / \delta$ signalling targets. We suggest that $\mathrm{p} 38 \gamma / \delta$ establish sustained tissue activation, which with time promotes tumour development. Our work broadens the understanding of functional redundancies in the p38MAPK family during skin tumour promotion, and demonstrates that both $\mathrm{p} 38 \gamma$ and $\mathrm{p} 38 \delta$ are involved in cytokine production in the skin, and are essential for skin tumour development.

\section{MATERIALS AND METHODS}

\section{Mice and experimental models}

Mice lacking p38 $\gamma, \mathrm{p} 38 \delta$ and $\mathrm{p} 38 \gamma / \delta$ have been described [25]. Mice were housed in specific pathogenfree conditions, and all animal procedures were performed in accordance with national and EU guidelines, with the approval of the Centro Nacional de Biotecnología Animal Ethics Committee.

For skin carcinogenesis experiments, the backs of 6-8 week-old female mice of the indicated genotypes were shaved. Two days later, the two-step DMBA/TPA carcinogenesis protocol was initiated using a single topical application of DMBA (100 $\mu \mathrm{g}$ in $200 \mu \mathrm{l}$ acetone; Sigma). The promotion phase consisted of biweekly TPA applications (10 $\mu \mathrm{g}$ in $200 \mu \mathrm{l}$ acetone; Sigma) for 19 weeks. Mice were examined regularly for tumour appearance and from week 15 tumour growth was measured with a calliper. Mice were sacrificed at week 29 and skin samples were processed for further analysis. Control mice were treated with acetone alone. This treatment was performed twice, with similar results. For short-term in vivo studies of epidermal apoptosis and DNA repair, dorsal skin of 6-8 week old female mouse was treated with a single DMBA application $(100 \mu \mathrm{g}$ in $200 \mu \mathrm{l}$ acetone) or acetone $(200 \mu \mathrm{l}) 2$ days after shaving and analysed $24 \mathrm{~h}$ later. For inflammation and proliferation assays, mouse dorsal skin was treated with a single topical TPA application (10 $\mu \mathrm{g}$ in $200 \mu \mathrm{l}$ acetone) or acetone 2 days after shaving and analysed at different times post-challenge. For proliferation assays, mice received intraperitoneal injections of $100 \mathrm{mg} \mathrm{BrdU} / \mathrm{kg}$ body weight in sterile PBS $2 \mathrm{~h}$ before sacrifice.

For signalling analysis, skin sections were lysed 
in $50 \mathrm{mM}$ Tris- $\mathrm{HCl} \mathrm{pH} 7.5,1 \mathrm{mM}$ EGTA, $1 \mathrm{mM}$ EDTA, $0.15 \mathrm{M} \mathrm{NaCl}, 1 \mathrm{mM}$ sodium orthovanadate, $10 \mathrm{mM}$ sodium fluoride, $50 \mathrm{mM}$ sodium $\beta$-glycerophosphate, $5 \mathrm{mM}$ pyrophosphate, $0.27 \mathrm{M}$ sucrose, $0.1 \mathrm{mM}$ phenylmethylsulphonyl fluoride, $1 \%(\mathrm{v} / \mathrm{v})$ Triton X-100 plus $0.1 \% \quad(\mathrm{v} / \mathrm{v})$ 2-mercaptoethanol. Lysates were centrifuged $\left(15,000 \mathrm{x}\right.$ g, $\left.15 \mathrm{~min}, 4^{\circ} \mathrm{C}\right)$, supernatants collected, quick-frozen in liquid nitrogen, and stored at $-80^{\circ} \mathrm{C}$.

\section{Antibodies}

Antibodies to total ERK1/2, active phosphorylated ERK1/2 (Thr202/Tyr204; P-ERK1/2), and to total JNK1/2, phospho-NFкB1/p105 (Ser933; P-p105), phospho-STAT3 (Tyr705; P-STAT3) and active phosphop38MAPK (Thr180-Tyr182; P-p38) were from Cell Signaling Technology. Anti-P-p38 antibody recognized all phosphorylated p38 isoforms, since the phosphorylation sites of all four p38MAPK are very similar, there are not specific phospho-p38 antibodies for each p38MAPK isoform. Anti-STAT3 and -p38 $\alpha$ were from Santa Cruz, anti-active phospho-JNK1/2 (Thr183-Tyr185; P-JNK) from Biosource, anti-BrdU and -myeloperoxidase (MPO) from Abcam, and anti-p38 $\gamma$ and $-\mathrm{p} 38 \delta$ antibodies were raised and purified as described [49, 50]. Anti-CD3, anti-F4/80, anti-CD45, anti- $\gamma \delta$ TCR and anti-Ly6G were from Dako Cytomation.

\section{Production and transduction of lentivirus short hairpin RNA (shRNA)}

For knockdown of endogenous human p38 $\gamma$ and $\mathrm{p} 38 \delta$, we used MISSION shRNA constructs in the pLKO.1-Puro lentiviral expression vector (Open

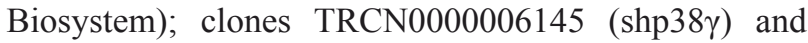
TRCN0000000827 (shp38 ) were used to knock down

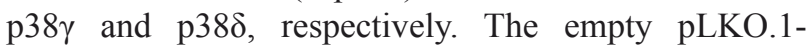
Puro vector was used as control. To produce lentiviral transduction particles, human embryonic kidney HEK$293 \mathrm{~T}$ cells growing in $35 \mathrm{~mm}$ dishes were cotransfected using the polyethyleneimine method with $1.5 \mu \mathrm{g}$ shRNAencoding plasmid, $0.2 \mu \mathrm{g} \mathrm{pRSV}-\mathrm{Rev}$ and $0.9 \mu \mathrm{g} \mathrm{pMDLg} /$ pRRE packaging plasmids, and $0.35 \mu \mathrm{g}$ envelope plasmid pMD2.G. Virus-containing medium was collected 24 and $48 \mathrm{~h}$ post-transfection. Medium from both time points was pooled, filtered $(0.45 \mathrm{~mm})$, aliquoted and stored $\left(-80^{\circ} \mathrm{C}\right)$. For lentiviral transduction of A431 cells, $1 \mathrm{ml}$ viral supernatant, $8 \mu \mathrm{g} / \mathrm{ml}$ polybrene and HEPES (10 mM final concentration) were added to $50 \%$ confluent cells in sixwell dishes. After 24 h, $0.5 \mathrm{ml}$ viral supernatant, $8 \mu \mathrm{g} / \mathrm{ml}$ polybrene and HEPES (10 $\mathrm{mM}$ final concentration) were added. Virus-containing medium was removed after $24 \mathrm{~h}$, and successfully infected cells were selected by $0.5 \mu \mathrm{g} / \mathrm{ml}$ puromycin addition to medium. Cells were maintained in medium with $0.5 \mu \mathrm{g} / \mathrm{ml}$ puromycin until harvest.

\section{Cell culture and lysis}

The human epithelial carcinoma cell line A431 and human embryonic kidney (HEK)-293T cells were maintained in DMEM supplemented with $10 \%$ foetal bovine serum (FBS), $4 \mathrm{mM} \mathrm{L-glutamine,} 100 \mathrm{IU} /$ $\mathrm{ml}$ penicillin and $0.1 \mathrm{mg} / \mathrm{ml}$ streptomycin (complete DMEM). Cells were lysed in $50 \mathrm{mM}$ Tris- $\mathrm{HCl} \mathrm{pH}$ 7.5, 1 mM EGTA, $1 \mathrm{mM}$ EDTA, $1 \mathrm{mM}$ sodium orthovanadate, $50 \mathrm{mM}$ NaF, $5 \mathrm{mM}$ pyrophosphate, $0.27 \mathrm{M}$ sucrose, 0.2 $\mathrm{mM}$ phenylmethylsulphonyl fluoride, 1\% Triton X-100 and $0.1 \%$ 2-mercaptoethanol. Lysates were centrifuged $\left(15,000 \mathrm{x} \mathrm{g}, 10 \mathrm{~min}, 4^{\circ} \mathrm{C}\right)$, supernatants quick-frozen, and stored at $-80^{\circ} \mathrm{C}$.

\section{Immunoblot}

Protein samples were resolved in SDS-PAGE and transferred to nitrocellulose membranes, blocked (30 min) in TBST buffer (50 mM Tris/ $\mathrm{HCl} \mathrm{pH} 7.5,0.15 \mathrm{M} \mathrm{NaCl}$, $0.1 \%(\mathrm{v} / \mathrm{v})$ Tween) with $5 \%(\mathrm{w} / \mathrm{v})$ dry milk, then incubated in TBST buffer with 5\% (w/v) dry milk and 0.5-1 $\mu \mathrm{g} / \mathrm{ml}$ antibody ( $2 \mathrm{~h}$, room temperature (RT) or overnight, $4^{\circ} \mathrm{C}$ ). Protein was detected using either horseradish peroxidaseconjugated secondary antibodies and the enhanced chemiluminescence reagent (Amersham Pharmacia Biotech), or fluorescently labelled secondary antibodies (Invitrogen) and the Odyssey infrared imaging system.

\section{Gene expression analysis}

cDNA for real-time quantitative PCR (qPCR) was generated from $0.5 \mu \mathrm{g}$ total RNA using High Capacity cDNA Reverse Transcription Kit (Applied Biosystems) in a $10 \mu \mathrm{l}$ final reaction volume. Real-time qPCR reactions were performed in triplicate using $5 \mu \mathrm{l} /$ well of a $1 / 40$ dilution of cDNA and 1x HOT FIREPol qPCR mix (Solis BioDyne) in an $8 \mu \mathrm{l}$ volume in MicroAmp Optical 384-well plates (Applied Biosystems). PCR reactions were carried out in an ABI PRISM 7900HT (Applied Biosystems) and results analysed by the comparative $\mathrm{Ct}$ method $(\Delta \Delta \mathrm{Ct})$ using SDS v2.2 software. X-fold induction in mRNA expression was quantified relative to unstimulated WT samples, and GAPDH mRNA was used as housekeeping gene. Primer sequences are listed in Table S1.

\section{Tumourigenicity assays (xenografts)}

For tumourigenicity assays in nude mice ( $\mathrm{nu}$ / $n u)$, A431 cells were resuspended in DMEM just before inoculation ( $10^{6}$ A431 cells $/ 0.1 \mathrm{ml} /$ mouse flank) and 
injected subcutaneously into immunosuppressed female nu/nu mice (Charles River Laboratories, Wilmington, MA). Tumor growth was monitored for approximately 3 weeks.

\section{Tumour analysis}

Tumour volume was calculated by the formula $V$ $=\left(D x d^{2}\right) / 2$, where $D$ and $d$ are the longest and shortest diameter in $\mathrm{mm}$, respectively.

\section{Keratinocyte isolation}

Full-thickness skin was taken from newborn mice and treated with $0.25 \%$ trypsin $1-300$ (INC Biomedicals) overnight at $4^{\circ} \mathrm{C}$. The epidermis was peeled off from the dermis and gently disrupted in Eagle's minimum essential medium (EMEM; Lonza) supplemented with 0.2 $\mathrm{mM} \mathrm{CaCl}, 4 \% \mathrm{FBS}$ pretreated with the chelating agent Chelex 100 and 1\% antibiotics. The cell suspension was filtered through a $100 \mu \mathrm{m}$ strainer, cells counted with a haemocytometer, and cultured on $6 \mathrm{~cm}$ plates in complete EMEM (1.5 x $10^{6}$ primary keratinocytes/plate). After $24 \mathrm{~h}$, the $\mathrm{Ca}^{2+}$ concentration in medium was decreased to $0.05 \mathrm{mM}$ and epidermal growth factor $(1 \mathrm{ng} / \mathrm{ml})$ was added to induce cell division. TPA $(20 \mathrm{nM})$ was applied to keratinocytes, which were collected $6 \mathrm{~h}$ after treatment for RNA extraction and qPCR analysis. Control keratinocytes were treated with DMSO alone.

\section{Histological analysis}

We used haematoxylin/eosin (H\&E)-stained skin. Thickness of the epidermal layer was measured in vertical cross-sections in at least 40 locations per mouse to determine hyperplasia.

Proliferation was determined by immunofluorescence in deparaffinised sections by antiBrdU staining. To detect proliferating cells, dewaxed sections were treated with $1 \mathrm{~N}$ ice-cold $\mathrm{HCl}$ (10 min), $2 \mathrm{~N}$ $\mathrm{HCl}$ (RT, $2 \mathrm{~h}$ ), washed extensively in $0.1 \mathrm{M}$ borate buffer, blocked with $5 \%$ goat serum in $0.25 \%$ Triton-PBS, and incubated overnight with a rat anti-BrdU antibody (1:100, Abcam) at RT. Anti-rat Alexa Fluor647 (Invitrogen) was used as secondary antibody. T cells were stained with anti-CD3 antibody (1:50, Dako) as described above (without $\mathrm{HCl}$-pre-treatment step) and detected using anti-CY3 antibody (Jackson Immunoresearch). MPOpositive cells were visualized by immunohistochemistry, using a biotinylated secondary antibody (Jackson Immunoresearch) and ABC (Vectastain)/3,3'diaminobenzidine (DAB, Vector Laboratories) signal amplification/detection method, followed by haematoxylin counterstaining and light microscopy analysis.
Apoptosis was determined by TUNEL staining. TUNEL-positive cells were counted on slides from 30 random fields/mouse from four mice. Slides were mounted for fluorescence with Hoechst33342-containing mounting medium (Sigma) and analysed with a TCS SP5 Microscope (Leica).

\section{Flow cytometry analysis}

Mouse skin was excised, cut into 1-2 mm pieces, washed once with PBS and incubated in DMEM with collagenase IV $(1 \mathrm{mg} / \mathrm{ml})$, DNase $(0.1 \mathrm{mg} / \mathrm{ml})\left(37^{\circ} \mathrm{C}, 1\right.$ h). Dissociated cells and digested tissue fragments were filtered $(70 \mu \mathrm{m})$ and $5 \mathrm{ml}$ staining PBS containing FBS and $5 \mathrm{mM}$ EDTA were added. Cells were collected by centrifugation $\left(1500 \mathrm{xg}, 10 \mathrm{~min}, 4^{\circ} \mathrm{C}\right)$ and washed once with staining PBS supplemented with 5 mM EDTA.

Skin cells were stained with combinations of fluorescence-labelled antibodies to cell surface markers CD45, CD3, $\gamma \delta$ TCR, Ly6G and F4/80, and analysed in a FACSCalibur cytometer (BD Biosciences). Profiles were analysed with FlowJo software (BD Biosciences); leukocytes were gated as $\mathrm{CD} 45^{+}$cells.

\section{Statistical analysis}

Differences in tumour multiplicity and incidence, as well as band intensities in immunoblots, were analysed by two-way ANOVA. Other data were processed using Student's t test. In all cases, $p$ values $<0.05$ were considered significant. Data are shown as mean $\pm \mathrm{SEM}$.

\section{ACKNOWLEDGMENTS}

We thank $\mathrm{P}$ Vaquero and $\mathrm{R}$ Gomez-Caro for technical support and C Mark for editorial assistance.

This work was supported by grants from the Ministerio de Economia y Competitividad (MINECO) (BFU2010-19734 and SAF2013-45331-R) to AC and MINECO (SAF2012-34378), Comunidad Autónoma de Madrid (S2010/BMD-2470, Oncocycle Programs) and ISCIII-RETIC RD12/0036/0009 to JMP. RZ received a la Caixa Foundation International Fellowship (la Caixa/ CNB).

\section{CONFLICTS OF INTEREST}

The authors declare that they have no conflict of interest.

\section{REFERENCES}

1. K.D. Brantsch, C. Meisner, B. Schonfisch, B. Trilling, J. Wehner-Caroli, M. Rocken, H. Breuninger, Analysis of risk 
factors determining prognosis of cutaneous squamous-cell carcinoma: a prospective study, Lancet Oncol, 2008, 9: 713720 .

2. J. Garcia-Zuazaga, S.M. Olbricht, Cutaneous squamous cell carcinoma, Adv Dermatol, 2008; 24: 33-57.

3. D. Hanahan, L.M. Coussens, Accessories to the crime: functions of cells recruited to the tumor microenvironment, Cancer Cell, 2012; 21: 309-322.

4. B. Baldursson, B. Sigurgeirsson, B. Lindelof, Leg ulcers and squamous cell carcinoma. An epidemiological study and a review of the literature, Acta Derm Venereol, 1993; 73: 171-174.

5. M.H. Motswaledi, C. Doman, Lupus vulgaris with squamous cell carcinoma, J Cutan Pathol, 2007; 34: 939941.

6. V. Ratushny, M.D. Gober, R. Hick, T.W. Ridky, J.T. Seykora, From keratinocyte to cancer: the pathogenesis and modeling of cutaneous squamous cell carcinoma, J Clin Invest, 2012; 122: 464-472.

7. J.E. Rundhaug, S.M. Fischer, Molecular mechanisms of mouse skin tumor promotion, Cancers (Basel), 2010; 2:436482.

8. C. Segrelles, S. Ruiz, P. Perez, C. Murga, M. Santos, I.V. Budunova, J. Martinez, F. Larcher, T.J. Slaga, J.S. Gutkind, J.L. Jorcano, J.M. Paramio, Functional roles of Akt signaling in mouse skin tumorigenesis, Oncogene, 2002; 21: 53-64.

9. J.S. Arthur, S.C. Ley, Mitogen-activated protein kinases in innate immunity, Nat Rev Immunol, 2013; 13: 679-692.

10. A. Risco, A. Cuenda, New Insights into the p38gamma and p38delta MAPK Pathways, J Signal Transduct, 2012; 2012: 520289.

11. A. Cuadrado, A.R. Nebreda, Mechanisms and functions of p38 MAPK signalling, Biochem J, 2010; 429: 403-417.

12. A. Cuenda, S. Rousseau, p38 MAP-kinases pathway regulation, function and role in human diseases, Biochim Biophys Acta, 2007;1773:1358-1375.

13. E.F. Wagner, A.R. Nebreda, Signal integration by JNK and p38 MAPK pathways in cancer development, Nat Rev Cancer, 2009; 9: 537-549.

14. A. Risco, C. del Fresno, A. Mambol, D. Alsina-Beauchamp, K.F. MacKenzie, H.T. Yang, D.F. Barber, C. Morcelle, J.S. Arthur, S.C. Ley, C. Ardavin, A. Cuenda, p38gamma and p38delta kinases regulate the Toll-like receptor 4 (TLR4)induced cytokine production by controlling ERK1/2 protein kinase pathway activation, Proc Natl Acad Sci U S A, 2012; 109: 11200-11205.

15. G. Criado, A. Risco, D. Alsina-Beauchamp, M.J. PerezLorenzo, A. Escos, A. Cuenda, Alternative p38 MAPKs are essential for collagen-induced arthritis, Arthritis Rheumatol, 2014; 66: 1208-1217.

16. P. Del Reino, D. Alsina-Beauchamp, A. Escos, M.I. CerezoGuisado, A. Risco, N. Aparicio, R. Zur, M. FernandezEstevez, E. Collantes, J. Montans, A. Cuenda, Pro- oncogenic role of alternative p38 mitogen-activated protein kinases p38gamma and p38delta, linking inflammation and cancer in colitis-associated colon cancer, Cancer Res, 2014; 74: 6150-6160.

17. B. Gonzalez-Teran, J.R. Cortes, E. Manieri, N. Matesanz, A. Verdugo, M.E. Rodriguez, A. Gonzalez-Rodriguez, A.M. Valverde, P. Martin, R.J. Davis, G. Sabio, Eukaryotic elongation factor 2 controls TNF-alpha translation in LPSinduced hepatitis, J Clin Invest, 2013; 123: 164-178.

18. M.I. Cerezo-Guisado, P.D. Reino, G. Remy, Y. Kuma, J.S. Arthur, D. Gallego-Ortega, A. Cuenda, Evidence of p38\{gamma\} and p38\{delta\} involvement in cell transformation processes, Carcinogenesis, 2011; 32: 10931099.

19. D. Faraone, M.S. Aguzzi, G. Toietta, A.M. Facchiano, F. Facchiano, A. Magenta, F. Martelli, S. Truffa, E. Cesareo, D. Ribatti, M.C. Capogrossi, A. Facchiano, Platelet-derived growth factor-receptor alpha strongly inhibits melanoma growth in vitro and in vivo, Neoplasia, 2009; 11: 732-742.

20. S.G. Iñesta-Vaquera F., Kuma Y and Cuenda A. , Alternative p38MAPK pathways. Stress activated protein kinases., 2008; 20: 17-32.

21. A. Kukkonen-Macchi, O. Sicora, K. Kaczynska, C. OetkenLindholm, J. Pouwels, L. Laine, M.J. Kallio, Loss of p38gamma MAPK induces pleiotropic mitotic defects and massive cell death, J Cell Sci, 2011; 124: 216-227.

22. C.C. Wu, X. Wu, J. Han, P. Sun, p38gamma regulates UVinduced checkpoint signaling and repair of UV-induced DNA damage, Protein Cell, 2010; 1: 573-583.

23. K. Yang, Y. Liu, Z. Liu, J. Liu, X. Liu, X. Chen, C. Li, Y. Zeng, p38gamma overexpression in gliomas and its role in proliferation and apoptosis, Sci Rep, 2013; 3: 2089.

24. E.M. Schindler, A. Hindes, E.L. Gribben, C.J. Burns, Y. Yin, M.H. Lin, R.J. Owen, G.D. Longmore, G.E. Kissling, J.S. Arthur, T. Efimova, p38delta Mitogen-activated protein kinase is essential for skin tumor development in mice, Cancer Res, 2009; 69: 4648-4655.

25. G. Sabio, J.S. Arthur, Y. Kuma, M. Peggie, J. Carr, V. Murray-Tait, F. Centeno, M. Goedert, N.A. Morrice, A. Cuenda, p38gamma regulates the localisation of SAP97 in the cytoskeleton by modulating its interaction with GKAP, EMBO J, 2005; 24: 1134-1145.

26. J.B. Swann, M.D. Vesely, A. Silva, J. Sharkey, S. Akira, R.D. Schreiber, M.J. Smyth, Demonstration of inflammation-induced cancer and cancer immunoediting during primary tumorigenesis, Proc Natl Acad Sci U S A, 2008; 105: 652-656.

27. D.R. Rhodes, S. Kalyana-Sundaram, V. Mahavisno, R. Varambally, J. Yu, B.B. Briggs, T.R. Barrette, M.J. Anstet, C. Kincead-Beal, P. Kulkarni, S. Varambally, D. Ghosh, A.M. Chinnaiyan, Oncomine 3.0: genes, pathways, and networks in a collection of 18,000 cancer gene expression profiles, Neoplasia, 2007; 9: 166-180.

28. T.J. Slaga, G.L. Gleason, J. DiGiovanni, K.B. Sukumaran, 
R.G. Harvey, Potent tumor-initiating activity of the 3,4-dihydrodiol of 7,12-dimethylbenz(a)anthracene in mouse skin, Cancer Res, 1979; 39: 1934-1936.

29. S.R. Dashti, T. Efimova, R.L. Eckert, MEK6 regulates human involucrin gene expression via a p38alpha - and p38delta -dependent mechanism, J Biol Chem, 2001; 276: 27214-27220.

30. C. Johansen, K. Kragballe, M. Westergaard, J. Henningsen, K. Kristiansen, L. Iversen, The mitogen-activated protein kinases p38 and ERK1/2 are increased in lesional psoriatic skin, Br J Dermatol, 2005; 152: 37-42.

31. J. DiGiovanni, Multistage carcinogenesis in mouse skin, Pharmacol Ther, 1992; 54: 63-128.

32. D. Wang, R.N. Dubois, A. Richmond, The role of chemokines in intestinal inflammation and cancer, Curr Opin Pharmacol, 2009; 9: 688-696.

33. F.O. Nestle, P. Di Meglio, J.Z. Qin, B.J. Nickoloff, Skin immune sentinels in health and disease, Nat Rev Immunol, 2009; 9: 679-691.

34. S.R. Dashti, T. Efimova, R.L. Eckert, MEK7-dependent activation of p38 MAP kinase in keratinocytes, J Biol Chem, 2001; 276: 8059-8063.

35. T. Efimova, A.M. Broome, R.L. Eckert, A regulatory role for p38 delta MAPK in keratinocyte differentiation. Evidence for $\mathrm{p} 38$ delta-ERK1/2 complex formation, J Biol Chem, 2003; 278: 34277-34285.

36. C. Kim, Y. Sano, K. Todorova, B.A. Carlson, L. Arpa, A. Celada, T. Lawrence, K. Otsu, J.L. Brissette, J.S. Arthur, J.M. Park, The kinase p38 alpha serves cell type-specific inflammatory functions in skin injury and coordinates proand anti-inflammatory gene expression, Nat Immunol, 2008; 9: 1019-1027.

37. G. Sabio, M.I. Cerezo-Guisado, P. Del Reino, F.A. InestaVaquera, S. Rousseau, J.S. Arthur, D.G. Campbell, F. Centeno, A. Cuenda, p38gamma regulates interaction of nuclear PSF and RNA with the tumour-suppressor hDlg in response to osmotic shock, J Cell Sci, 2010; 123: 25962604.

38. J. Tang, X. Qi, D. Mercola, J. Han, G. Chen, Essential role of p38gamma in K-Ras transformation independent of phosphorylation, J Biol Chem, 2005; 280: 23910-23917.

39. S. Sano, K.S. Chan, J. DiGiovanni, Impact of Stat3 activation upon skin biology: a dichotomy of its role between homeostasis and diseases, J Dermatol Sci, 2008; 50: 1-14.

40. T.R. Medler, L.M. Coussens, Duality of the immune response in cancer: lessons learned from skin, J Invest Dermatol, 2014; 134: E23-28.

41. S. Grivennikov, E. Karin, J. Terzic, D. Mucida, G.Y. Yu, S. Vallabhapurapu, J. Scheller, S. Rose-John, H. Cheroutre, L. Eckmann, M. Karin, IL-6 and Stat3 are required for survival of intestinal epithelial cells and development of colitisassociated cancer, Cancer Cell, 2009; 15: 103-113.

42. N. Maas-Szabowski, A. Shimotoyodome, N.E. Fusenig,
Keratinocyte growth regulation in fibroblast cocultures via a double paracrine mechanism, J Cell Sci, 1999; 112 (Pt 12): 1843-1853.

43. R.J. Moore, D.M. Owens, G. Stamp, C. Arnott, F. Burke, N. East, H. Holdsworth, L. Turner, B. Rollins, M. Pasparakis, G. Kollias, F. Balkwill, Mice deficient in tumor necrosis factor-alpha are resistant to skin carcinogenesis, Nat Med, 1999; 5: 828-831.

44. T. Schioppa, R. Moore, R.G. Thompson, E.C. Rosser, H. Kulbe, S. Nedospasov, C. Mauri, L.M. Coussens, F.R. Balkwill, B regulatory cells and the tumor-promoting actions of TNF-alpha during squamous carcinogenesis, Proc Natl Acad Sci U S A, 2011; 108: 10662-10667.

45. C. Cataisson, A.J. Pearson, M.Z. Tsien, F. Mascia, J.L. Gao, S. Pastore, S.H. Yuspa, CXCR2 ligands and G-CSF mediate PKCalpha-induced intraepidermal inflammation, $\mathrm{J}$ Clin Invest, 2006; 116: 2757-2766.

46. L.A. Pekarek, B.A. Starr, A.Y. Toledano, H. Schreiber, Inhibition of tumor growth by elimination of granulocytes, J Exp Med, 1995; 181: 435-440.

47. T. Jamieson, M. Clarke, C.W. Steele, M.S. Samuel, J. Neumann, A. Jung, D. Huels, M.F. Olson, S. Das, R.J. Nibbs, O.J. Sansom, Inhibition of CXCR2 profoundly suppresses inflammation-driven and spontaneous tumorigenesis, J Clin Invest, 2012; 122: 3127-3144.

48. A. Ittner, H. Block, C.A. Reichel, M. Varjosalo, H. Gehart, G. Sumara, M. Gstaiger, F. Krombach, A. Zarbock, R. Ricci, Regulation of PTEN activity by p38delta-PKD1 signaling in neutrophils confers inflammatory responses in the lung, J Exp Med, 2012; 209: 2229-2246.

49. A. Cuenda, P. Cohen, V. Buee-Scherrer, M. Goedert, Activation of stress-activated protein kinase-3 (SAPK3) by cytokines and cellular stresses is mediated via SAPKK3 (MKK6); comparison of the specificities of SAPK3 and SAPK2 (RK/p38), EMBO J, 1997; 16: 295-305.

50. M. Goedert, A. Cuenda, M. Craxton, R. Jakes, P. Cohen, Activation of the novel stress-activated protein kinase SAPK4 by cytokines and cellular stresses is mediated by SKK3 (MKK6); comparison of its substrate specificity with that of other SAP kinases, EMBO J, 1997; 16: 3563-3571. 